\title{
36. STABLE AND RADIOGENIC ISOTOPES IN PORE WATERS FROM LEG 127, JAPAN SEA ${ }^{1}$
}

\author{
H.-J. Brumsack, ${ }^{2}$ E. Zuleger, ${ }^{3}$ E. Gohn, ${ }^{2}$ and R. W. Murray ${ }^{4}$
}

\begin{abstract}
Interstitial waters from four sites of the Japan Sea (794 to 797$)$ have been analyzed for stable isotopes $\left(\delta \mathrm{D}, \delta^{11} \mathrm{~B}, \delta^{18} \mathrm{O}\right.$, and $\delta^{34} \mathrm{~S}$ ) and ${ }^{87} \mathrm{Sr} /{ }^{86} \mathrm{Sr}$, besides major and minor ions. The isotopic composition is dominated by organic matter degradation, alteration of ash layers and volcaniclastic sands, silica transformation (opal A/CT), and basement alteration.

Organic matter degradation and corresponding sulfate reduction leads to ${ }^{32} \mathrm{~S}$ depletion and is dependent upon sedimentation rate. The remaining sulfate reservoir is characterized by very "heavy" $\delta^{34} \mathrm{~S}$ ratios, up to $+93 \%$ (rel. CDT = Canyon Diabolo Troilite). "Barite fronts," which may develop in such sediments, should also be characterized by very "heavy" sulfur isotopes.

The alteration of volcaniclastic material in the Quaternary sections influences the $\delta^{18} \mathrm{O}\left(-1.5 \%\right.$ o shift) and $\delta^{11} \mathrm{~B}$ (desorption and later adsorption of "labile" $\left.{ }^{11} \mathrm{~B}\right)$. A pronounced positive $\delta^{11} \mathrm{~B}$ anomaly at Site 795 represents the depth range of preferential ${ }^{10} \mathrm{~B}$ uptake by alteration products of the ash layers. At Site $796 \delta \mathrm{D}, \delta^{11} \mathrm{~B}$, and ${ }^{87} \mathrm{Sr} /{ }^{86} \mathrm{Sr}$ are severely affected by alteration processes of volcaniclastic sands.

The opal A/CT transformation may influence the oxygen isotopes and serves as a potential source for B, which is liberated at this interval at Site 795. This positive B anomaly is not reflected in the $\delta^{11} \mathrm{~B}$ profile.

Basement alteration processes dominate the sedimentary sequence below the opal A/CT transition, which serves as a chemical and physical boundary. The decreases in $\delta \mathrm{D}$ and $\delta^{18} \mathrm{O}$ are probably related to a "paleo ocean water reservoir" situated in the permeable Layer II of the oceanic crust, as is indicated by the positive correlation between these two parameters. Besides Mg, alkalies and $\delta^{18} \mathrm{O}$ basement rocks also serve as a sink for ${ }^{11} \mathrm{~B}$ (Site 795) and are the source for the $\mathrm{Ca}$ and $\mathrm{Sr}$ increases, as is documented by the less radiogenic ${ }^{87} \mathrm{Sr} /{ }^{86} \mathrm{Sr}$ ratio.

${ }^{87} \mathrm{Sr} /{ }^{86} \mathrm{Sr}$ ratios for the lowermost pore waters from Site $795(0.70529)$ are comparable to those from volcaniclastic rocks from the "Green Tuff" region ( 0.704 to 0.706$)$ and oil field brines from the Niigata Oil Field.
\end{abstract}

\section{INTRODUCTION}

The Japan Sea, situated between the Eurasian Continent and the Japanese island arc, is one of the most intensively studied back-arc basins of the western Pacific. It is characterized by a complicated seafloor topography, including depressions such as the Japan and Yamato Basins (Iijima et al., 1988; Tamaki, 1988). There is no deep-water connection between the Japan Sea and the western Pacific since sill depths at present are shallower than $150 \mathrm{~m}$ (Ingle, Suyehiro, von Breymann, et al., 1990).

Four sites (794 to 797) were drilled during ODP Leg 127 (Fig. 1), two (794 and 797) in the Yamato Basin and two (795 and 796) in the Japan Basin. Site 796, situated on Okushiri Ridge, was uplifted 1.8 Ma ago (Tamaki, Pisciotto, Allan, et al., 1990). Five lithofacies generally dominate the sedimentary sequence:

1. Quaternary to Pliocene, partly laminated silty clays,

2. Pliocene to upper Miocene diatom ooze,

3. Middle to upper Miocene diatom clay with chert layers,

4. Middle to upper Miocene calcareous and siliceous claystone, and

5. Lower Miocene volcaniclastic sandstones and siltstones.

The lowermost sedimentary sequences from early to early middle Miocene represent the initial development of the basins and comprise volcaniclastic sand- and siltstones, often interlayered with basaltic sills. The following stage (early Miocene to early middle Miocene) characterizes the rapid deepening of the basins. Sediments comprise

\footnotetext{
' Pisciotto, K. A., Ingle, J. C., Jr., von Breymann, M. T., Barron, J., et al., 1992. Proc. ODP, Sci. Results, 127/128, Pt. 1: College Station, TX (Ocean Drilling Program).

${ }^{2}$ Geochemisches Institut der Universität Göttingen, Goldschmidtstr. 1, D-3400 Göttingen, Federal Republic of Germany.

${ }^{3}$ Institut für Geowissenchaften und Lithosphärenforschung der Universität Giessen, Senckenbergstr, 3, D-6300 Giessen, Federal Republic of Germany.

${ }^{4}$ University of California at Berkeley, Department of Geology and Geophysics. Berkeley, CA 94720 , U.S.A.
}

fine-grained, diatomaceous and calcareous clay-rich pelagic and hemipelagic muds and minor tuff.

Sedimentation during the late Miocene and Pliocene is characterized by an increase in diatom productivity due to upwelling. Oxic conditions must have prevailed, as total organic carbon (TOC) contents of the sediments rarely exceed $1 \%$.

The Quaternary sequence is characterized by alternations of darkcolored, laminated silty clays and light-colored, bioturbated silty clays, possibly reflecting changes in bottom water oxygenation. Organic matter contents may reach $7.4 \%$ and average $1.3 \%$ in this interval. Tephra layers are quite abundant (Tamaki, Pisciotto, Allan, et al., 1990).

Pore waters were retrieved from all four sites drilled (794 to 797) during Leg 127 of the ODP, to document early and late diagenetic reactions within the sedimentary column and alteration of the basement rocks.

\section{SAMPLING AND ANALYTICAL METHODS}

Detailed sampling has been performed for the upper part of the sedimentary column and around the Opal A/Opal CT transition zone. Nearly 100 samples were recovered during Leg 127 and analyzed for up to 22 parameters.

Interstitial water samples were squeezed from $5-\mathrm{cm}$ whole round samples immediately after retrieval of the cores. Besides the conventional steel squeezing device (Manheim and Sayles, 1974), a newly developed metal-free squeezer (see appendix) was utilized. Sediment samples for the metal-free squeezer were stored and processed in a nitrogen-flushed glove box to prevent oxidation artifacts. Samples were acidified and kept in precleaned PE screw-top bottles. Subsamples were kept in PC vials and analyzed for major and some minor ions on board ship along with the samples from the conventional stainless steel squeezer. Details of the sampling procedure and a comparison of the results obtained by both squeezers are presented in the appendix. 


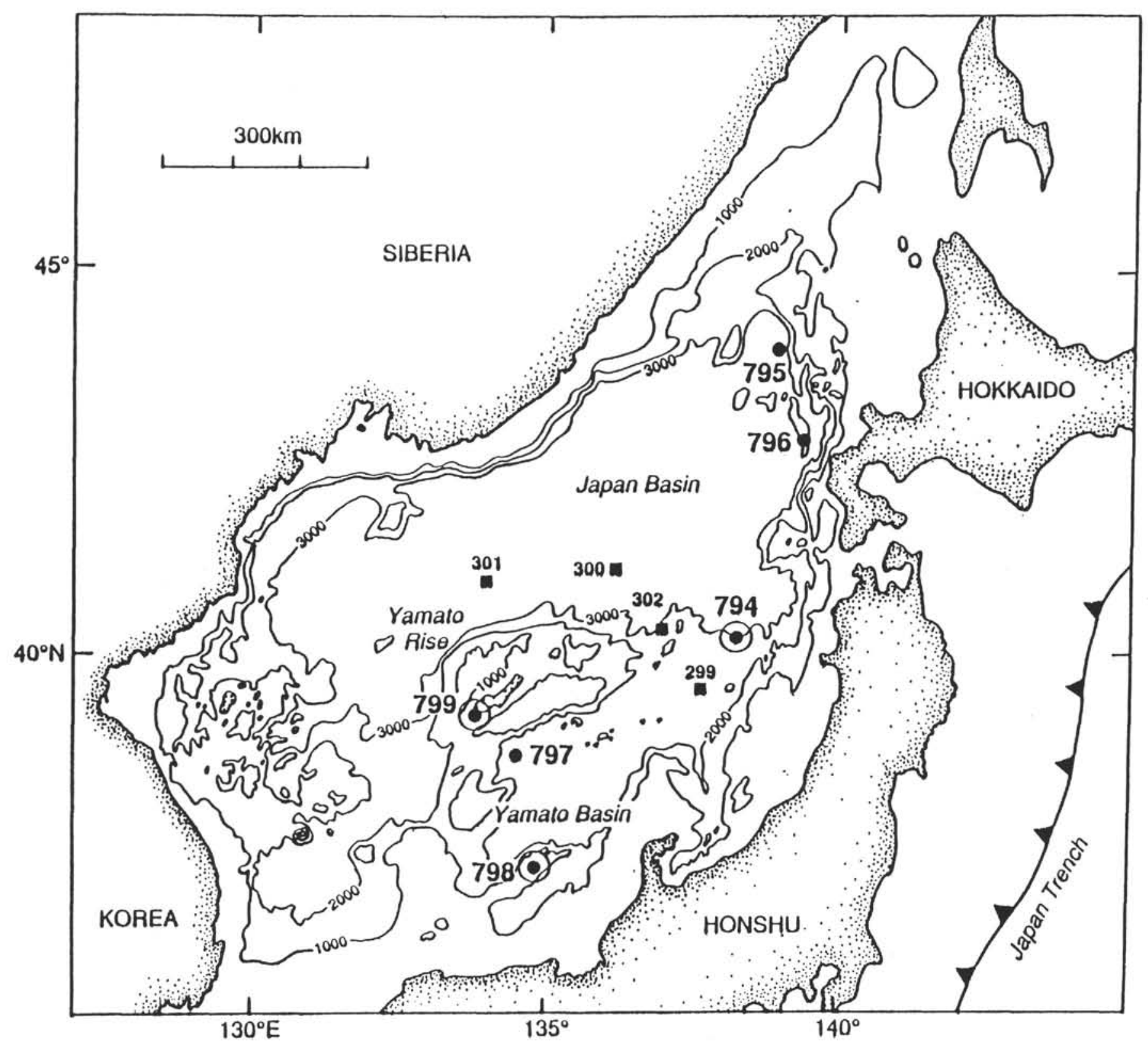

Figure 1. Map of the Japan Sea and the locations of DSDP/ODP Sites. Contours are in meters.

Samples from both squeezing devices have been analyzed on board ship by titrimetric, colorimetric, and chromatographic methods described by Gieskes and Peretsman (1986). Li, K, and Rb have been analyzed by Flame Atomic Emission Spectrometry (FAES) after appropriate dilution. Calibration solutions were obtained by mixing a $3 \% \mathrm{NaCl}$-solution with different volumes of seawater or by spiking with the appropriate metals.

Shorebased studies included the determination of $\mathrm{Sr}, \mathrm{Ba}, \mathrm{B}, \mathrm{Mn}$, and Fe by ICP AES (ARL $35000 \mathrm{C}$ ) on 1:10 dilutions of the original sample with deionized water. Calibration curves were obtained by spiking an acidified $3 \% \mathrm{NaCl}$ solution or Japan Sea surface water with appropriate amounts of the metals.

Oxygen isotopes were determined on separate sample splits that have been sealed in glass ampoules. Two different preparation techniques were applied to most samples. The first method involved reaction of $10 \mu \mathrm{L}$ samples with $\mathrm{BrF}_{5}$ and conversion of the $\mathrm{O}_{2}$ released to $\mathrm{CO}_{2}$. For the second method, $100 \mu \mathrm{L}$ of the water was sealed with
$3.5 \mathrm{~mL}$ of $\mathrm{CO}_{2}$ gas in 2-mL glass ampoules and equilibrated at $25^{\circ} \mathrm{C}$ in a thermostat for at least 3 days. The $\mathrm{CO}_{2}$ was then analyzed for its isotopic composition on a Finnigan MAT 251 mass spectrometer. To check the accuracy of the preparation technique, three international water samples were analyzed as well (SLAP $=$ Standard Light Antarctic Precipitation, GISP = Greenland Ice Sheet Precipitation, and SMOW $=$ Standard Mean Ocean Water). The reproducibility was generally better than $\pm 0.3 \%$ o. All values are given as per mil deviation relative to $\mathrm{SMOW}$, where

$$
\delta^{18} \mathrm{O}(\text { in } \mathrm{o} / 00)=\left(\frac{\left({ }^{18} \mathrm{O} /{ }^{16} \mathrm{O}\right)_{\text {sample }}}{\left({ }^{18} \mathrm{O} /{ }^{16} \mathrm{O}\right)_{\text {standard }}}-1\right) \cdot 1000 .
$$

Hydrogen isotopes were determined on $10-\mu \mathrm{L}$ samples of interstitial waters after reduction of water by $\mathrm{U}$ at $800^{\circ} \mathrm{C}$ and trapping of hydrogen on activated charcoal immersed in liquid nitrogen. The 
deuterium/hydrogen was then analyzed for its isotopic composition on a Finnigan MAT 251 mass spectrometer. Three international water samples were analyzed as well (SLAP, GISP, and SMOW). The reproducibility was generally better than $\pm 0.5 \%$. All values are given as per mil deviation relative to SMOW, where the $\delta$-value is defined as above.

Sulfur isotopes were determined on pore waters previously used for shipboard alkalinity determinations. The sulfate was precipitated as barite and converted to $\mathrm{H}_{2} \mathrm{~S}$ by a tin(II)-phosphoric acid reaction (Kiba and Kishi, 1957). The liberated $\mathrm{H}_{2} \mathrm{~S}$ was precipitated as $\mathrm{CdS}$, converted to $\mathrm{Ag}_{2} \mathrm{~S}$ and after filtration and drying reacted with $\mathrm{V}_{2} \mathrm{O}_{5}$ in sealed quartz glass ampoules at $1000^{\circ} \mathrm{C}$. The $\mathrm{SO}_{2}$ was analyzed on a Finnigan MAT 251 mass spectrometer. The reproducibility was generally better than $\pm 0.2 \%$. All values are given as per mil deviation relative to the Canyon Diabolo Troilite (CDT) standard, where the $\delta$-value is defined as above.

Sr isotopes were determined on a Finnigan MAT 261 solid source mass spectrometer in multicollector static mode at the Institut für Geowissenschaften und Lithosphärenforschung at the University of Giessen (F.R.G.).

After separation by conventional cation exchange techniques, $\mathrm{Sr}$ was loaded with phosphoric acid on Ta single filaments. Mass fractionation of $\mathrm{Sr}$ was corrected to ${ }^{87} \mathrm{Sr} /{ }^{86} \mathrm{Sr}=8.375209$. The analytical errors of ${ }^{87} \mathrm{Sr} /{ }^{86} \mathrm{Sr}$ determinations are smaller than $\pm 3 \cdot 10^{-5}(2 \sigma)$. The value obtained for the NBS-987 Sr standard was $0.710235 \pm$ $0.000008(2 \sigma)$ and represents the average from 15 analyses carried out during this study. Total blanks for $\mathrm{Sr}$ are less than $0.15 \mathrm{ng}$; the $\mathrm{Sr}$ content of separated samples was larger than $2 \mathrm{mg}$.

B isotopes were determined on the above-mentioned Finnigan MAT 261 solid source mass spectrometer in negative thermionization mode $\left({ }^{10} \mathrm{BO}_{2^{-}}=\right.$mass 42 and $11 \mathrm{BO}_{2^{-}}=$mass 43$)$. Pore waters $(25$ to $50 \mathrm{ng} \mathrm{B})$ were directly loaded on Re filaments. Thirty scans, each lasting $8 \mathrm{~s}$, were performed for each sample. Values are reported in the $\delta$ scale, relative to NBS SRM 951 boric acid, where the $\delta$-value is defined as above for $\delta^{18} \mathrm{O}$.

The analytical errors of $\delta^{11} \mathrm{~B}$ determinations are less than $\pm 0.5 \%$ $(2 \sigma)$, based on replicate analysis. The ${ }^{11} \mathrm{~B} /{ }^{10} \mathrm{~B}$ value obtained for the NBS SRM 951 boric acid standard was $4.0104 \pm 0.0033(2 \sigma)$. There is a constant offset $\left[\left({ }^{11} \mathrm{~B} /{ }^{10} \mathrm{~B}\right)_{\text {STDanalyzed }}\right]$ to the reported value $\left[\left({ }^{11} \mathrm{~B} /{ }^{10} \mathrm{~B}_{\mathrm{STD}}\right)=\right.$ 4.0437], therefore all data were corrected $\left[\left({ }^{11} \mathrm{~B} /{ }^{10} \mathrm{~B}\right)_{\text {car. }}\right]$ according to:

$$
\left({ }^{11} \mathrm{~B} /{ }^{10} \mathrm{~B}\right)_{\text {corr. }}=\frac{\left({ }^{11} \mathrm{~B} /{ }^{10} \mathrm{~B}\right)_{\text {analyzed }} \cdot\left({ }^{11} \mathrm{~B} /{ }^{10} \mathrm{~B}\right)_{\mathrm{STD}}}{\left({ }^{11} \mathrm{~B} /{ }^{10} \mathrm{~B}\right)_{\text {STDanalyzed }}}
$$

This offset is a common feature of B isotope determinations in negative thermionization mode.

\section{RESULTS AND DISCUSSION}

\section{Sulfate and Sulfur Isotopes}

All four sites investigated are characterized by more or less intense sulfate reduction (Fig. 2) due to the availability of metabolizable organic matter in the sediments. Whereas sulfate reduction is essentially complete in the upper parts of Sites 795 and 796 (Japan Basin), substantial amounts of sulfate are still present in the pore waters of Sites 794 and 797 (Yamato Basin). The sulfate decrease seems to be directly related to the rate of sediment accumulation as the total amount of organic matter is essentially the same at all sites.

To differentiate between the given possibilities, the sulfur-isotopic composition of the pore water sulfate was determined on selected samples (Table 1). As can be seen in Figure 2, the remaining sulfate reservoir becomes progressively more positive with increasing depth. The "heaviest" sulfur isotopes are found at Site 797 , where $\delta^{34} S$ values reach more than $+93 \%$ (rel. CDT) around 180 mbsf. These data are among the heaviest ever reported for natural marine pore waters. Samples from deeper downcore show a trend toward decreasing $\delta^{34} S$ values. It cannot be precluded that the lowermost sample from Site 795 is slightly contaminated by seawater $\left(\delta^{34} \mathrm{~S}\right.$ value around $+20 \%$ \% $)$.

The increase in sulfate concentration at greater depth, which was observed especially at Sites 796 and 797, therefore may represent a sulfate reservoir that has not been utilized. Probably the diffusive supply of sulfate from the former sediment/water interface was larger (due to lower sediment accumulation rates) than bacterial sulfate consumption, thus creating a sulfate reservoir at depth. On the other hand, the supply of sulfate from a deeply seated reservoir in Layer II cannot be completely excluded.

At Site 796 both the sulfate and the sulfur-isotope profiles are quite different from those at the other sites investigated. Sulfate reduction is complete at rather shallow depths and reoccurs at about $100 \mathrm{mbsf}$. Besides organic matter the bacteria may also feed on methane, which was present at this site in large quantities (methane clathrates; Tamaki, Pisciotto, Allan, et al., 1990).

Berner (1978) has shown a relationship between sediment accumulation and sulfate reduction rates. Goldhaber and Kaplan (1980) also considered sulfur isotopic variations of dissolved pore water sulfate and used the term $S \delta$ (product of sulfate concentration and $\delta^{34} \mathrm{~S}$ ), which was calculated as a function of depths for several values of the fractionation factor $\alpha$. The relationship between sediment accumulation rate and sulfate reduction is also evident from Figure 3. Here the product of the sulfate fraction remaining in solution and the $\delta^{34} \mathrm{~S}$ value $\left[\left(\mathrm{SO}_{4} p w / \mathrm{SO}_{4} s w\right) \cdot \delta \Phi 255 \perp 34 \Sigma=\Sigma \phi \delta\right]$ is plotted vs. depth for Sites 794,795 , and 797 . For all these sites an essentially linear relationship of $\mathrm{Sf} \delta$ with depths is apparent. For comparison, data from the Gulf of California upwelling sediments (Brumsack, 1986), which accumulate at a rate of about $1000 \mathrm{~m} / \mathrm{Ma}$, are given as well.

The Sf $\delta$ value used here roughly represents the amount of ${ }^{32} \mathrm{~S}$ present at the different depths. In slowly accumulating sediments the ${ }^{32} \mathrm{~S}$ reservoir is not completely exhausted because diffusion accounts for the supply of the light ${ }^{32} \mathrm{~S}$ isotope. Evidently Site 794, where sediments accumulate at a rate of about $35 \mathrm{~m} / \mathrm{Ma}$, shows the smallest decrease of Sf $\delta$ with burial depth. A much steeper decrease is displayed at Site $797(50 \mathrm{~m} / \mathrm{Ma})$ and Site $795(63 \mathrm{~m} / \mathrm{Ma})$.

These results may also be reflected in the $\delta^{34} \mathrm{~S}$ values of the sediments. Ronov et al. (1974) could empirically show that sediments that accumulated rapidly are less enriched in ${ }^{32} \mathrm{~S}$ than those deposited under lower sedimentation rates.

Another consequence of the almost complete absence of pore water sulfate due to microbial activity is the development of "barite fronts" (Brumsack, 1986; von Breymann et al., this volume). Diatomaceous sediments often contain considerable amounts of "biogenic barite." Small barite crystals seem to form during degradation of organic matter within siliceous tests (Bishop, 1988). Excess Ba concentrations in sediments have been used for paleoproductivity reconstructions (Schmitz, 1987). But in anoxic sediments these authigenic barites dissolve in the depth range of complete pore water sulfate depletion (Brumsack and Gieskes, 1983; Brumsack, 1986). Therefore, high $\mathrm{Ba}$ concentrations (up to $1000 \mu \mathrm{M}$ ) were detected in sulfate-free pore waters from Site 795 (Fig. 4).

While sulfate diffuses downward from the sediment/seawater interface, Ba diffuses upward from deeper intervals, where sulfate is absent. A zone of barite precipitation and dissolution, the "barite front," develops in the depth range of almost complete sulfate absence. The diagenetic barites that precipitate should be isotopically heavy because the sulfur isotopic composition of the remaining pore water sulfate reservoir has $\delta^{34} S$ values around $+60 \%$ (rel. CDT). The most likely depth of the "barite front" at Site 795 lies at about 75 mbsf (Fig. 4).

Diagenetic barite nodules may form in such an environment, when sedimentation rates decrease. In this case the "barite front" will stop at a certain depth and record the change in $\delta^{34} \mathrm{~S}$ of the pore water sulfate reservoir during growth. Barite nodules from banks in the 

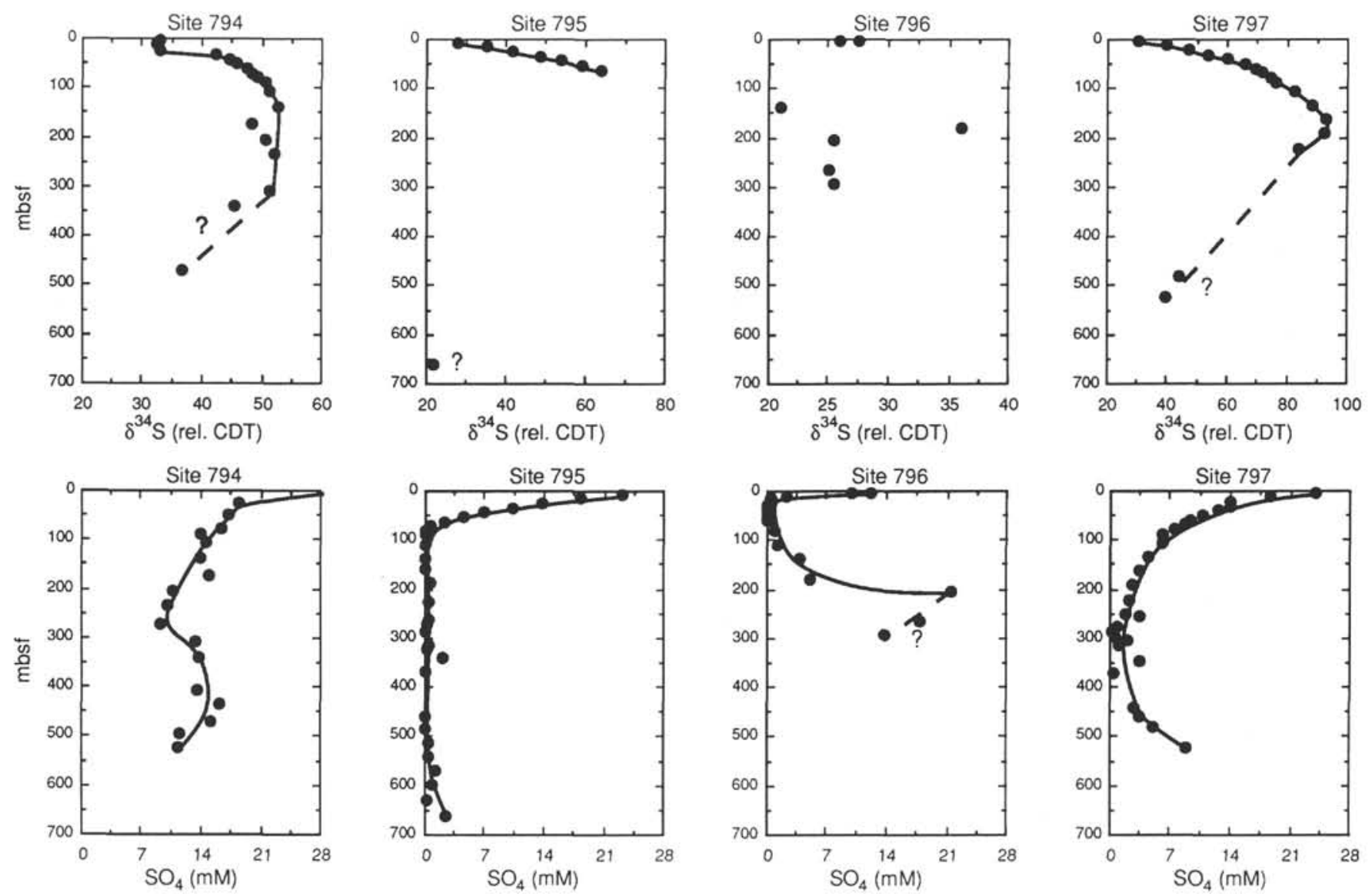

Figure 2. Sulfate and sulfur isotopes in interstitial waters from the Japan Sea.

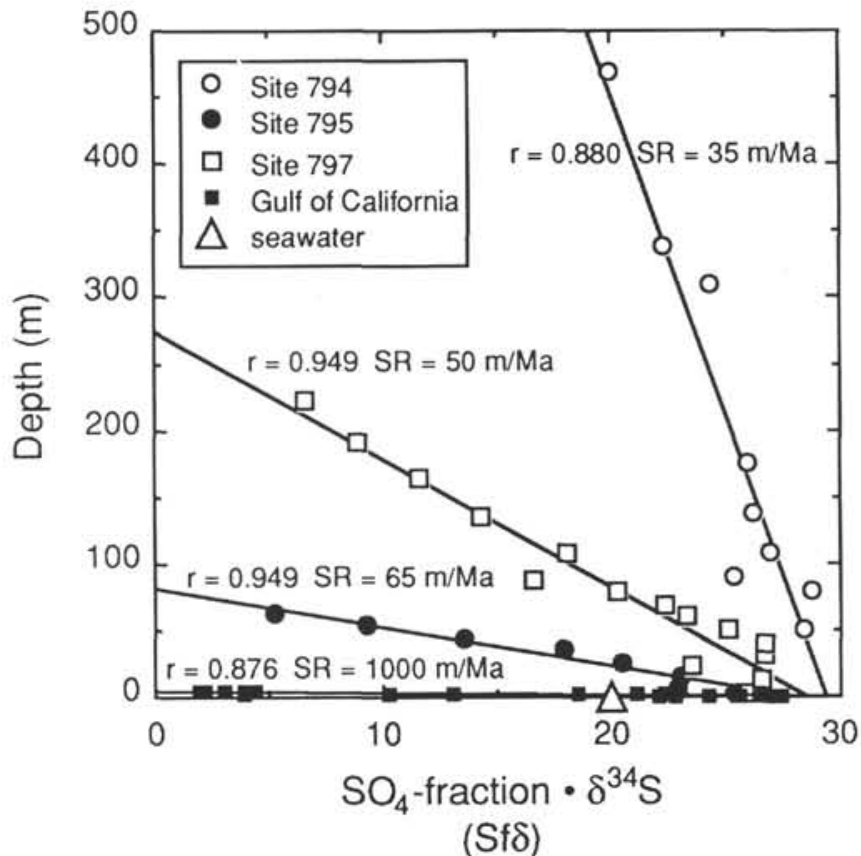

Figure 3. Sf $\delta$ vs. depth for Sites 794, 795, 797, and upwelling sediments from the Gulf of California (Brumsack, 1986).
Japan Sea that have been analyzed by Sakai (1971) are isotopically very heavy; consequently they seem to have formed in a similar diagenetic environment.

\section{Boron and Boron Isotopes}

Even though B is one of the major ions in seawater $(0.42 \mathrm{mM}$; Bruland, 1983), it has not commonly been investigated in pore waters from drill cores recovered during DSDP/ODP. Manheim et al. (1972) reported an increase of B with depth at DSDP Site 116 (HattenRockall Basin) but were unable to explain it. Other data fall within analytical error, and systematic gradients have not been observed. From their pore water studies of surface sediments Spivack et al. (1987) state that the early diagenetic flux of B into the sedimentary column is relatively unimportant but that fixation may be occurring at greater depths at higher temperatures beyond the "diffusive limit." On the other hand, B is fixed in alteration products during low-temperature alteration of the oceanic crust. There has also been much concern about squeezing effects (Spivack et al., 1987).

Here we report the first "consistent" B profiles obtained from drill cores in the Japan Sea (Table 1). Even though temperature and pressure effects cannot be completely excluded, the data seem to be reliable because concentrations from shallow cores are close to seawater values and consistent trends do not depend upon recovered water volume, applied pressure, or squeezing temperature.

The B profiles of Sites 794 and 797 from the Yamato Basin (Fig. 5) look remarkably similar. Here B concentrations are close to seawater values at the core tops. Then a small positive B anomaly centers at 
Table 1. Stable isotopes in pore waters from Leg 127.

\begin{tabular}{|c|c|c|c|c|c|c|c|}
\hline Core no. & mbsf & $\mathrm{B}(\mathrm{mM})$ & $\delta^{11} \mathrm{~B}$ & $\mathrm{SO}_{4}(\mathrm{mM})$ & $\delta^{34} \mathrm{~S}$ & $\delta^{18} \mathrm{O}$ & $\delta \mathrm{D}$ \\
\hline \multicolumn{8}{|l|}{ Site 794} \\
\hline IH & 4.5 & 0.42 & 39.80 & & 33.00 & & \\
\hline $2 \mathrm{H}$ & 11.3 & 0.60 & 36.20 & & 32.40 & & \\
\hline $3 \mathrm{H}$ & 23.8 & 0.51 & 37.70 & 18.5 & 33.00 & -0.22 & \\
\hline $4 \mathrm{H}$ & 31.8 & 0.51 & 37.60 & & 42.30 & -0.92 & \\
\hline $5 \mathrm{H}$ & 41.3 & 0.46 & 39.20 & & 44.60 & -1.00 & \\
\hline $6 \mathrm{H}$ & 50.8 & 0.42 & 42.20 & 17.3 & 45.90 & -1.08 & \\
\hline $7 \mathrm{H}$ & 60.3 & 0.51 & 40.60 & & 47.70 & & \\
\hline $8 \mathrm{H}$ & 69.8 & 0.37 & 41.20 & & 48.50 & & \\
\hline $9 \mathrm{H}$ & 79.2 & 0.37 & 41.80 & 16.4 & 49.20 & -1.06 & \\
\hline $10 \mathrm{H}$ & 88.8 & 0.37 & 43.20 & 14.0 & 50.60 & & \\
\hline $12 \mathrm{H}$ & 107.8 & 0.42 & 44.80 & 14.7 & 51.40 & -1.55 & \\
\hline $15 \mathrm{H}$ & 136.2 & 0.42 & 39.20 & 13.9 & 52.80 & & \\
\hline $19 \mathrm{X}$ & 174.4 & 0.42 & 41.60 & 15.0 & 48.50 & -2.16 & \\
\hline $22 \mathrm{X}$ & 203.4 & 0.46 & 40.00 & 10.8 & 50.70 & -2.68 & \\
\hline $25 \mathrm{X}$ & 232.4 & 0.46 & 38.20 & 10.2 & 52.00 & -3.16 & \\
\hline $29 \mathrm{X}$ & 271.4 & 0.42 & 38.60 & 9.3 & & -3.91 & \\
\hline $33 \mathrm{X}$ & 309.2 & 0.28 & 43.20 & 13.3 & 51.40 & -4.12 & \\
\hline $36 \mathrm{X}$ & 337.9 & 0.32 & 40.50 & 13.7 & 45.60 & -4.13 & \\
\hline $12 \mathrm{R}$ & 406.4 & 0.37 & 35.10 & 13.6 & & -4.59 & \\
\hline ISR & 435.2 & 0.23 & 38.70 & 16.2 & & -3.97 & \\
\hline $18 \mathrm{R}$ & 468.6 & 0.23 & 41.30 & 15.2 & 36.80 & -4.27 & \\
\hline $21 R$ & 496.1 & 0.14 & 41.30 & 11.5 & & -4.41 & \\
\hline $24 \mathrm{R}$ & 523.6 & 0.18 & 43.90 & 11.3 & & -4.81 & \\
\hline \multicolumn{8}{|l|}{ Site 795} \\
\hline $1 \mathrm{H}$ & 6.0 & 0.47 & 38.40 & 23.1 & 27.80 & -0.20 & -3.0 \\
\hline $2 \mathrm{H}$ & 15.3 & 0.47 & 39.20 & 18.3 & 35.20 & -0.40 & -3.9 \\
\hline $3 \mathrm{H}$ & 24.8 & 0.44 & 39.40 & 13.7 & 41.80 & -0.80 & -7.4 \\
\hline $4 \mathrm{H}$ & 34.8 & 0.57 & 44.40 & 10.3 & 48.80 & -1.00 & -5.2 \\
\hline $5 \mathrm{H}$ & 43.2 & 0.44 & 46.10 & 7.0 & 54.00 & -1.10 & -9.3 \\
\hline $6 \mathrm{H}$ & 53.8 & 0.53 & 44.70 & 4.4 & 58.90 & & -5.0 \\
\hline $7 \mathrm{H}$ & 62.8 & 0.49 & 47.50 & 2.3 & 63.80 & -1.20 & -6.0 \\
\hline $8 \mathrm{H}$ & 72.3 & 0.44 & 51.30 & 0.7 & & -1.30 & -8.3 \\
\hline $9 \mathrm{H}$ & 81.8 & 0.45 & 50.50 & 0.0 & & & \\
\hline $\mathrm{IOH}$ & 86.8 & 0.51 & 44.90 & 0.0 & & -1.10 & -7.8 \\
\hline $12 \mathrm{H}$ & 110.2 & 0.57 & 49.30 & 0.0 & & -2.20 & -8.6 \\
\hline $15 \mathrm{H}$ & 138.8 & 0.68 & 44.60 & 0.0 & & -1.60 & -8.1 \\
\hline $18 \mathrm{H}$ & 158.8 & 0.92 & 40.80 & 0.0 & & -2.20 & -11.5 \\
\hline $21 x$ & 187.6 & 1.07 & 38.80 & 0.7 & & -2.70 & -8.9 \\
\hline $25 \mathrm{X}$ & 224.8 & 1.13 & 37.70 & 0.5 & & -3.20 & -11.5 \\
\hline $29 X$ & 262.4 & 1.43 & 33.60 & 0.4 & & -3.00 & -13.2 \\
\hline $30 \mathrm{X}$ & 272.3 & 1.42 & 35.00 & 0.2 & & -3.50 & -12.3 \\
\hline $31 X$ & 285,1 & 1.55 & 32.00 & 0.1 & & -4.70 & -12.0 \\
\hline $34 X$ & 315.4 & 1.70 & 33.00 & 0.4 & & -4.10 & -12.5 \\
\hline $35 x$ & 320.6 & 1.65 & 32.40 & 0.2 & & -4.90 & -13.1 \\
\hline $37 X$ & 339.8 & 1.40 & 28.70 & 2.0 & & -4.50 & -11.8 \\
\hline IR & 366.6 & 1.74 & 27.40 & 0.0 & & -5.10 & -13.9 \\
\hline $10 \mathrm{R}$ & 457.9 & 1.30 & 27.90 & 0.1 & & & \\
\hline $13 R$ & 483.9 & 1.54 & 22.50 & 0.1 & & -4.80 & \\
\hline $16 \mathrm{R}$ & 511.2 & 0.63 & 21.00 & 0.4 & & -3.90 & \\
\hline $19 \mathrm{R}$ & 540.1 & 0.95 & 20.70 & 0.4 & & -3.70 & \\
\hline
\end{tabular}

around $12 \mathrm{mbsf}$, indicating release of a "labile" B fraction into the pore waters (Fig. 6). Deeper downcore B more or less consistently decreases toward the basement. This implies that B is removed from the interstitial waters and possibly becomes fixed in alteration products (smectites/illites, chlorites) of the volcanic ash layers and/or basement rocks. This removal is much more evident below the opal A/CT transition and may be related to elevated temperatures in this zone.

The profiles of Sites 795 and 796 in the Japan Basin look much more complicated (Fig. 5). At Site 795, which is characterized by rather intense alteration reactions below the opal A/CT transition, concentrations remain more or less constant in the upper $100 \mathrm{~m}$ of the sediments. Then an increase toward the silica transformation at about 320 mbsf is observable, implying a B source at this depth interval. Below this zone, $B$ decreases to below seawater values and seems to be removed, as in the other cores. Assuming a release of B at the opal $\mathrm{A} / \mathrm{CT}$ transition, there does not seem to be a diffusive connection to
Table 1 (continued).

\begin{tabular}{lrrrrrrr}
\hline Core no. & mbsf & $\mathrm{B}(\mathrm{mM})$ & $\delta^{11} \mathrm{~B}$ & $\mathrm{SO}_{4}(\mathrm{mM})$ & $\delta^{34} \mathrm{~S}$ & $\delta^{18} \mathrm{O}$ & $\delta \mathrm{D}$ \\
\hline 22R & 570.1 & 0.87 & 27.30 & 1.2 & & -3.80 & \\
25R & 598.1 & 0.55 & 27.30 & 0.9 & & -3.70 & -14.1 \\
8R & 628.6 & 0.29 & 21.30 & 0.3 & & -4.30 & \\
31R & 662.0 & 0.29 & 24.80 & 2.4 & 21.60 & -3.10 & \\
& & & & & & & \\
Site 796 & & & & & & & \\
& & & & & & & \\
1H & 2.1 & 0.86 & 30.10 & 10.0 & 27.50 & 0.04 & -0.9 \\
$2 \mathrm{H}$ & 9.2 & 1.72 & 28.70 & 2.3 & & -0.55 & -5.9 \\
3H & 14.2 & 2.29 & 28.60 & 0.4 & & -1.01 & -6.7 \\
$4 \mathrm{H}$ & 26.7 & 2.82 & 28.90 & 0.0 & & -1.48 & -8.3 \\
5H & 39.2 & 3.37 & 23.70 & 0.0 & & -1.35 & \\
6H & 50.2 & 2.23 & 24.80 & 0.0 & & -1.27 & -10.5 \\
8H & 58.7 & 2.57 & 18.30 & 0.4 & & -1.19 & -9.9 \\
$9 \mathrm{X}$ & 61.7 & 2.66 & 22.90 & 0.0 & & -1.30 & \\
$11 \mathrm{X}$ & 79.8 & 1.95 & 17.80 & 0.9 & & -1.11 & -9.9 \\
14X & 110.6 & 2.17 & 20.10 & 1.3 & & -1.17 & -5.9 \\
17X & 139.5 & 1.17 & 16.20 & 3.8 & 21.02 & -1.25 & \\
21X & 181.0 & 0.82 & 11.50 & 5.1 & 36.14 & -1.18 & \\
24X & 205.6 & 0.48 & 14.70 & 21.6 & 25.50 & -1.51 & \\
1R & 3.0 & 0.92 & 29.20 & 12.1 & 25.96 & & \\
12R & 263.8 & 0.14 & 19.40 & 17.8 & 25.05 & -1.51 & \\
$15 \mathrm{R}$ & 294.3 & 0.27 & 22.40 & 13.8 & 25.48 & -1.46 & \\
& & & & & & &
\end{tabular}

Site 797

\begin{tabular}{|c|c|c|c|c|c|c|c|}
\hline $1 \mathrm{H}$ & 3.0 & 0.59 & 36.50 & 24.0 & 30.21 & -0.37 & -1.4 \\
\hline $2 \mathrm{H}$ & 11.9 & 0.69 & 35.90 & 18.6 & 39.96 & -0.84 & -1.7 \\
\hline $3 \mathrm{H}$ & 22.9 & 0.65 & 37.50 & 13.9 & 47.51 & -1.35 & -4.2 \\
\hline $4 \mathrm{H}$ & 30.9 & 0.55 & 37.90 & 13.9 & 53.68 & -1.13 & -2.3 \\
\hline $5 \mathrm{H}$ & 40.4 & 0.48 & 38.50 & 12.5 & 59.79 & -1.06 & -4.1 \\
\hline $6 \mathrm{H}$ & 49.9 & 0.46 & 40.20 & 10.7 & 65.59 & -1.39 & -2.4 \\
\hline $7 \mathrm{H}$ & 59.4 & 0.45 & 41.00 & 9.4 & 69.45 & -1.49 & -3.8 \\
\hline $8 \mathrm{H}$ & 68.9 & 0.43 & 41.80 & 8.7 & 71.82 & -1.25 & \\
\hline $9 \mathrm{H}$ & 78.4 & 0.39 & 44.10 & 7.6 & 74.41 & -1.87 & \\
\hline $10 \mathrm{H}$ & 87.9 & 0.42 & 43.00 & 6.1 & 76.24 & -1.61 & \\
\hline $12 \mathrm{H}$ & 106.9 & 0.43 & 43.50 & 6.1 & 82.69 & -1.57 & \\
\hline $15 \mathrm{H}$ & 135.4 & 0.41 & 45.50 & 4.5 & 88.58 & -2.32 & -7.9 \\
\hline $18 \mathrm{H}$ & 163.9 & 0.44 & 45.10 & 3.5 & 93.14 & -2.92 & \\
\hline $21 X$ & 191.5 & 0.43 & 45.20 & 2.7 & 92.28 & -4.05 & -9.9 \\
\hline $24 \mathrm{X}$ & 221.8 & 0.44 & 45.60 & 2.2 & 83.93 & -3.97 & \\
\hline $27 \mathrm{X}$ & 252.4 & 0.46 & 44.40 & 1.8 & & -3.97 & \\
\hline $28 \mathrm{X}$ & 254.6 & 0.43 & 44.40 & 3.5 & & -4.41 & -15.8 \\
\hline $29 X$ & 274.0 & & & 0.9 & & -4.80 & \\
\hline $30 \mathrm{X}$ & 288.1 & 0.43 & 44.10 & 0.3 & & -6.24 & \\
\hline $32 \mathrm{X}$ & 296.4 & 0.40 & 45.30 & 0.6 & & -5.45 & \\
\hline $33 \mathrm{X}$ & 304.4 & 0.31 & 45.70 & 2.1 & & -4.90 & -15.9 \\
\hline $34 \mathrm{X}$ & 314.2 & & & 1.1 & & -5.28 & \\
\hline $37 X$ & 346.3 & 0.30 & 43.60 & 3.5 & & -4.60 & \\
\hline $40 \mathrm{X}$ & 370.0 & 0.22 & 44.50 & 0.4 & & -5.99 & -18.6 \\
\hline $47 \mathrm{X}$ & 440.6 & & & 2.9 & & & \\
\hline $49 X$ & 460.0 & 0.31 & 39.70 & 3.5 & & -6.50 & \\
\hline $51 x$ & 480.9 & 0.29 & 41.10 & 5.0 & 44.18 & -6.43 & \\
\hline $5 \mathrm{R}$ & 525.0 & 0.12 & 43.50 & 9.0 & 39.91 & -7.69 & \\
\hline
\end{tabular}

the sediment/seawater interface. Instead, the site of B removal is most likely situated in the zone of more abundant ash layers at around 100 mbsf. In the lower part of the sedimentary column B is removed during basement alteration.

At Site 796 a pronounced B maximum is present at shallow depths. Values are as much as eight times seawater. This anomaly coincides with the first appearance of volcanic sand layers. On the other hand, methane clathrates are also present at this depth interval (Tamaki, Pisciotto, Allan, et al., 1990). Unfortunately whether B is concentrated above seawater values in methane-hydrate water is unknown. A relatively good negative correlation between $\mathrm{B}$ and $\mathrm{Cl}$ exists (Fig. 7), which suggests that an association of B with gas hydrates cannot be excluded. B might be released from a solid phase as well, possibly altered acidic tuffs, which are present in the sands. Since B is a very incompatible element, it is enriched in residual granitic melts, andesitic tuffs, and volcanic glasses (Harder, 1973). Site 796 is 


$$
\mathrm{SO}_{4}(\mathrm{mM})
$$

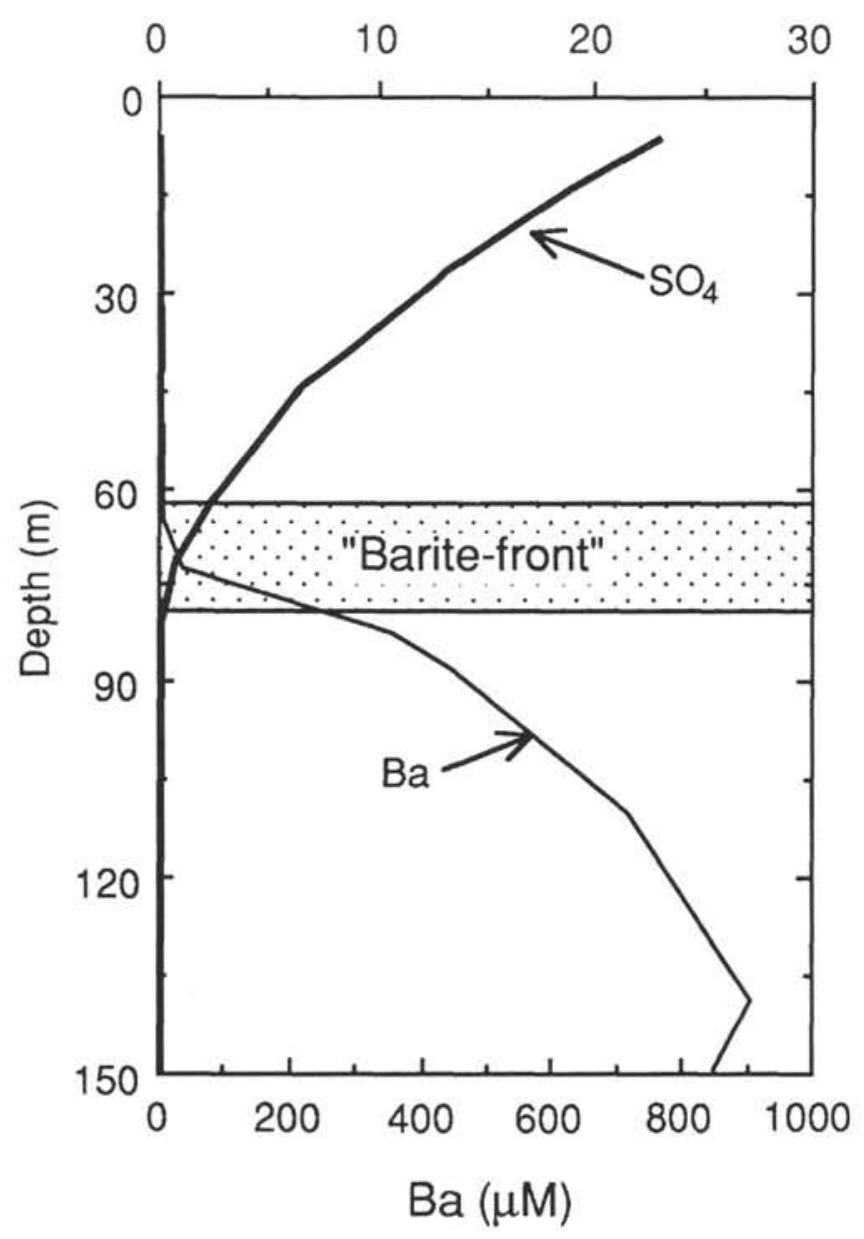

Figure 4. Profiles of $\mathrm{Ba}$, sulfate, and $\delta^{34} \mathrm{~S}$ in pore waters from ODP Site 795.

characterized by extreme $\mathrm{Mg}$ removal and alkalinity consumption at shallow depth, which is indicative of very intense ash alteration reactions (Gieskes et al., 1990b).

Another possible, though less likely, mechanism may be related to the adsorption of a "labile" B fraction during transit of the sands and especially tuffs through the water column before burial. This B may be liberated during alteration of this material. The large positive $B$ departure then should be similar to the much smaller anomaly seen in the upper parts of Sites 794 and 797 (Fig. 6).

Finally, it should be mentioned that a small fraction of the B may also be associated with organic matter (Harder, 1973) and could be released during bacterial degradation of this material. Site 796 is characterized by the steepest pore water sulfate decrease (see Fig. 2) and the presence of hydrogen sulfide at shallow depths (Tamaki, Pisciotto, Allan, et al., 1990). On the other hand, Site 795 does not show such an anomaly although it is as well characterized by intense bacterial sulfate reduction.

The B isotope and concentration profiles (Fig. 5 and Table 1) display a similar distribution at Sites 794 and 797. Only small deviations from seawater values (around $+40 \%$ rel. SRM 951 boric acid) are seen. Generally, a "light" B fraction is preferentially removed from pore waters by adsorption processes. The remaining solution then exhibits more positive $\delta^{11} \mathrm{~B}$ values (Spivack et al., 1987; Palmer and Sturchio, 1990). The desorption process of a "labile" B fraction during early diagenesis then should be reflected in the interstitial waters by a positive anomaly in B concentration and a corresponding negative deviation in $\delta^{11} \mathrm{~B}$. This mechanism seems to be responsible for the profiles seen in Sites 794 and 797 (Fig. 6). Deeper downcore the different modes of adsorption/desorption are responsible for the small shifts in $\delta^{11} \mathrm{~B}$, depending on lithology. At Site 797 adsorption processes seem to dominate, forcing the pore waters to become enriched in ${ }^{11} \mathrm{~B}$ by about $5 \%$ relative to seawater.

In contrast to the sites from the Yamato Basin, Sites 795 and 796 from the Japan Basin exhibit much more complicated B and $\delta^{11} \mathrm{~B}$ profiles (Fig. 5). The most intriguing detail at Site 795 is the broad positive $\delta^{11} \mathrm{~B}$ anomaly that is more than $10 \%$ "heavier" than seawater at about $100 \mathrm{mbsf}$. This is exactly the depth interval where B seems to be removed from the pore waters. Adsorption is the only process that can account for these observations. Surprisingly, the broad B maximum around the opal $\mathrm{A} / \mathrm{CT}$ transition is not reflected in the $\delta^{11} \mathrm{~B}$ profile. From the depth interval of B adsorption at $100 \mathrm{mbsf}$, where the positive $\delta^{11} \mathrm{~B}$ anomaly occurs, the $\delta^{11} \mathrm{~B}$ values consistently decrease by $30 \%$ down to the basement. This may be understood in terms of an uptake process operating at depth. Perhaps the transformation of smectites to illites may exert an important control as well. Only the analysis of the solids, especially the newly formed alteration products, will provide an answer to the unknown sink of the isotopically "heavy" B, which seems to be removed from the interstitial 

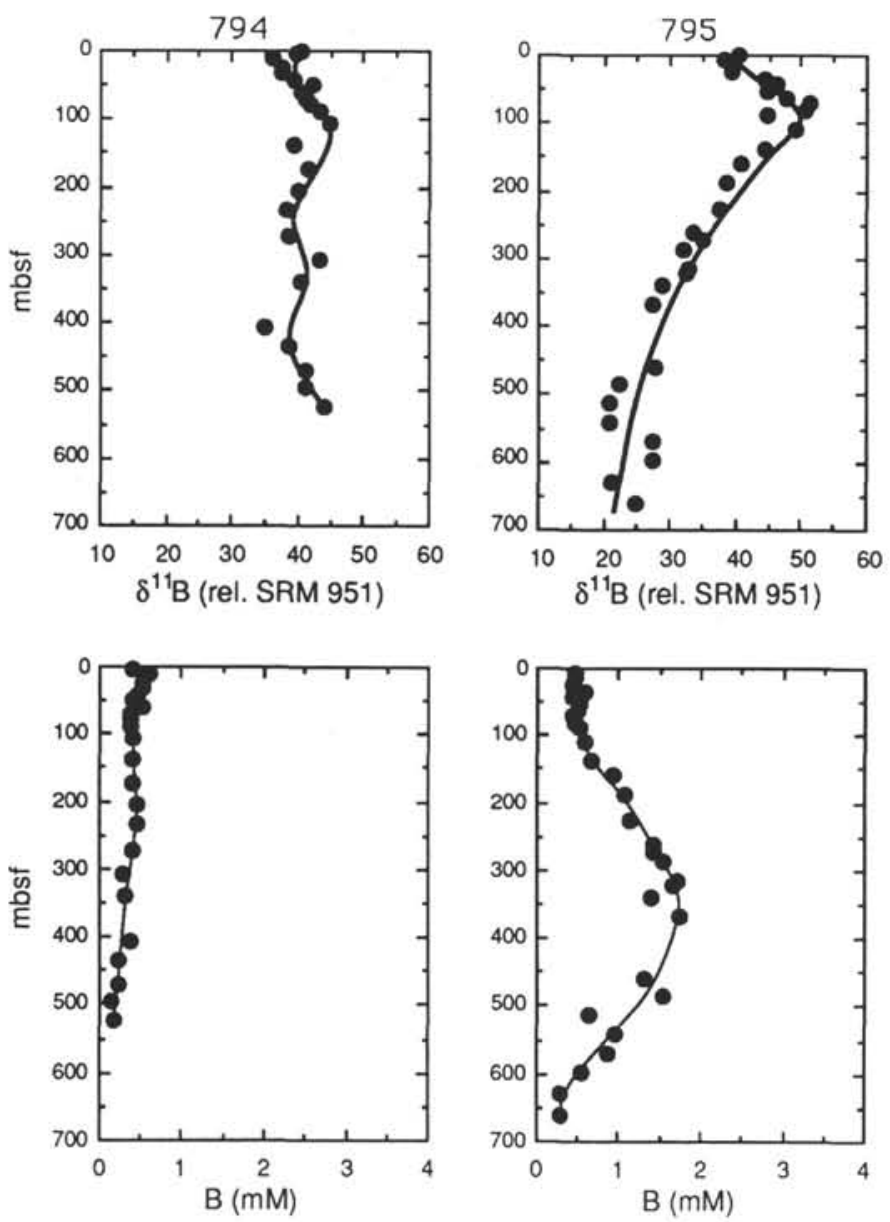

Figure 5. Boron concentration and $\delta^{11} \mathrm{~B}$ in pore waters from the Japan Sea.

waters. At Site 795, alteration reactions involving the basement rocks influence not only the major ion chemistry of the interstitial waters but also the $\mathrm{B}$ and $\delta^{11} \mathrm{~B}$ profiles.

Site 796 is characterized by a broad, negative $\delta^{11} \mathrm{~B}$ anomaly of about $30 \%$ o relative to seawater. This $\delta^{11} \mathrm{~B}$ excursion centers around 150 mbsf (Fig. 5), below the strong increase in B concentration at 50 mbsf. Since a negative $\mathrm{Mg}$ anomaly was observed at this site, which corresponds to a Li maximum (Tamaki, Pisciotto, Allan, et al., 1990), a volcanic source seems likely. The good negative correlation of B with Mg (Fig. 8) supports this hypothesis. The island arc volcanic sands should have $\delta^{11} \mathrm{~B}$ values around $0 \%$ (Spivack, 1986). This material may represent the source for the observed B anomaly and would shift the $\delta^{11} \mathrm{~B}$ to more negative values. At the same time B is removed from the interstitial waters deeper downcore.

A desorption process, comparable to the one operating at Sites 794 and 797 but with different magnitude, cannot be excluded. But because the $\mathrm{B}$ maximum does not correspond to the much broader $\delta^{11} \mathrm{~B}$ anomaly, this process seems less plausible. Also the decomposition of methane clathrates, which may be enriched in B, would by analogy to $\delta \mathrm{D}$ and $\delta^{18} \mathrm{O}$ probably lead to a positive anomaly, opposite to the observed trend.

The $\mathrm{B}$ and $\delta^{11} \mathrm{~B}$ profiles of the interstitial waters demonstrate that the behavior of this element is much more complicated during early diagenesis than previously thought. Adsorption/desorption processes and alteration reactions within the sedimentary column and in the basement rocks govern the distribution of this element in the pore fluids and should also influence the B content and isotopic composition of the alteration products, mainly clay minerals.
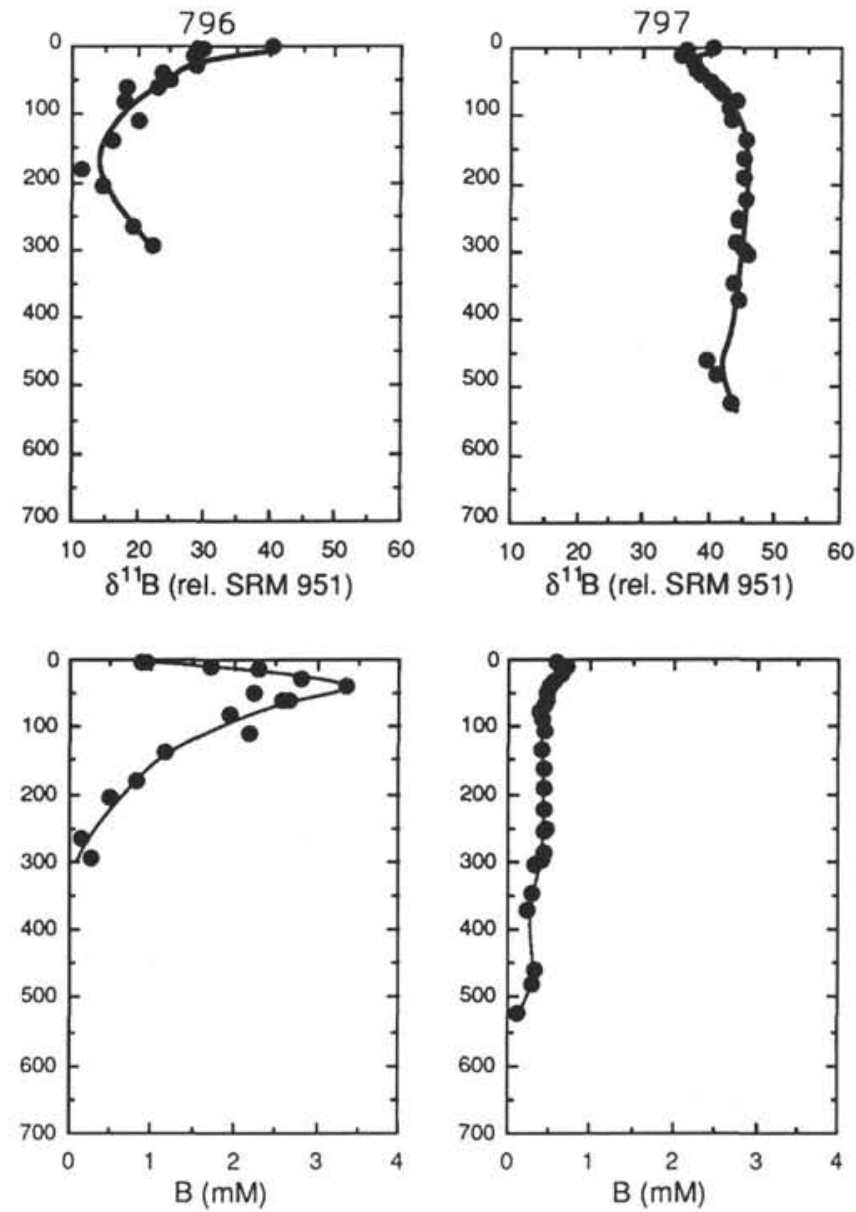

\section{Hydrogen and Oxygen Isotopes}

The oxygen isotopic composition of the pore waters has been determined for all sites (Fig. 9 and Table 1). The $\delta^{18} \mathrm{O}$ profiles seem to be controlled by essentially three processes (Kastner and Gieskes, 1976; Perry et al., 1976; Gieskes and Lawrence, 1981; Lawrence and Gieskes, 1981; Gieskes et al., 1990a, b):

1. Alteration of volcanic ash layers in the Quaternary sediments of Unit I;

2. Opal A/CT transformation at around $300 \mathrm{mbsf}$; and

3. Low-temperature alteration of basement rocks in Layer II, especially at Site 795.

A common feature of all profiles, with the exception of Site 796, is the decrease in $\delta^{18} \mathrm{O}$ with depth. At all sites an initial shift of about $-1.5 \%$ is observed in the ash-rich hemipelagic Quaternary clays of Unit I. This shift may be attributed to the alteration of these ash layers. The methane clathrates do not seem to have a distinct influence on the oxygen isotopic composition of the pore waters, since the strong $\delta^{18} \mathrm{O}$ decrease at the core tops is opposite to the trend expected from gas hydrate decomposition (Jenden and Gieskes, 1983).

At Sites 794, 795, and $797 \delta^{18} \mathrm{O}$ decreases at an essentially constant rate toward the opal A/CT transition. Cherts have the highest $\delta^{18} \mathrm{O}$ values found in rocks (Hoefs, 1987) and may change the oxygen isotopic composition of the pore waters toward more negative values. Below this zone a much smaller decrease is observed at Sites 794 and 797 , whereas a $\delta^{18} \mathrm{O}$ increase with depth is seen at Site 795 , probably 


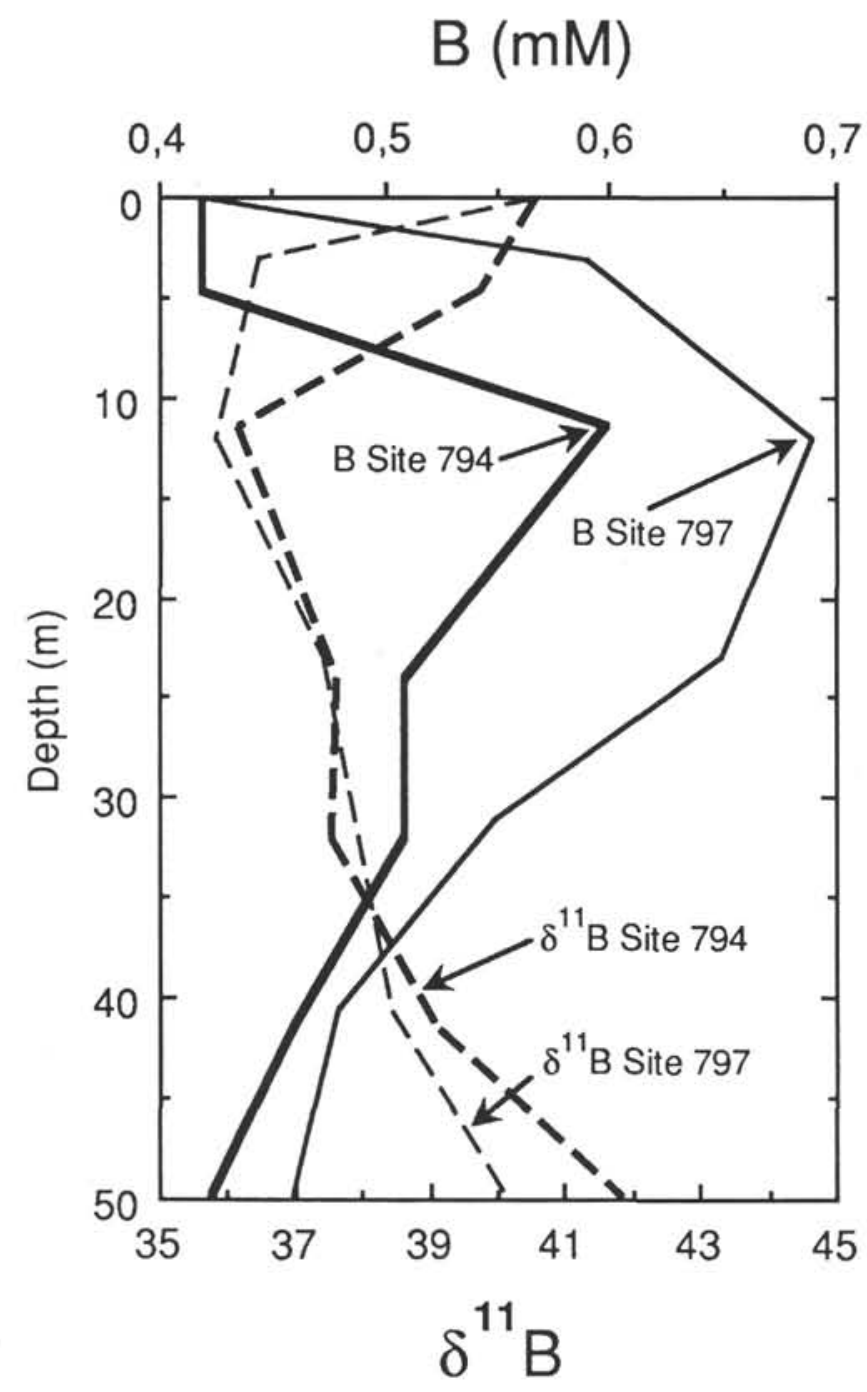

Figure 6. Boron concentration and $\delta^{11} \mathrm{~B}$ in pore waters from the upper $50 \mathrm{~m}$ of sediment in the Japan Sea.

related to elevated temperatures. This site is characterized by strong signals from basement alteration processes. The chert layers act as a physical boundary, separating two regimes with different chemical characteristics (Tamaki, Pisciotto, Allan, et al., 1990).

The basement rocks act as a sink not only for $\mathrm{Mg}$ and alkali metals but also for ${ }^{18} \mathrm{O}$. The relationship between $\mathrm{Li}$ and $\delta^{18} \mathrm{O}$, which was found in many altered spilitic rocks (Mengel and Hoefs, 1990), confirms the importance of this process. On the other hand, Lawrence and Gieskes (1981) discuss the possibility of a large "paleo ocean water reservoir," which may exist in the highly permeable upper portions of layer II. Diffusive exchange of this reservoir with seawater through the sedimentary column would then provide an alternative explanation of the observed trends in $\delta^{18} \mathrm{O}$.

$\mathrm{D} / \mathrm{H}$ ratios may serve as tracers of alteration reactions as well. In contrast to oxygen isotopes, $\mathrm{D} / \mathrm{H}$ ratios should not be affected by reactions at the opal $\mathrm{A} / \mathrm{CT}$ transition. More likely, alteration reactions involving clay mineral formation and the exchange with a "paleo ocean water reservoir" are the processes responsible for the shape of $\mathrm{D} / \mathrm{H}$ pore water profiles.

The D/H profiles of Sites 795 and 797 are rather similar. A more or less steady decrease from seawater values around $0 \%$ (rel. SMOW) at the core tops to values that are 15 to $25 \%$ "lighter" is seen. The good correlation between $\delta \mathrm{D}$ and $\delta^{18} \mathrm{O}$ (Fig. 10) strongly

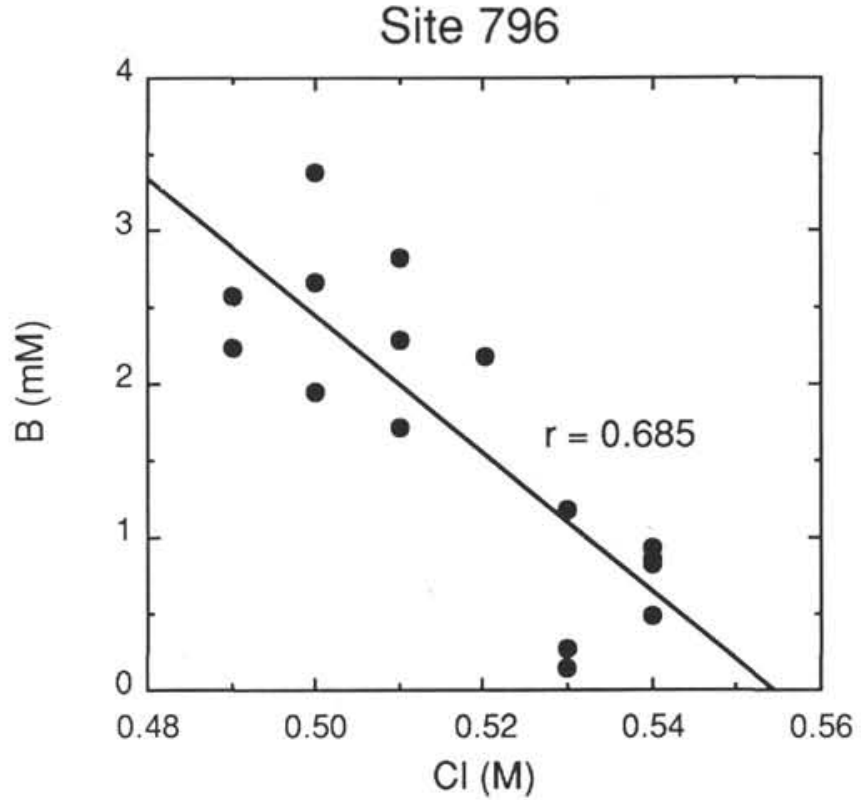

Figure 7. Correlation between $\mathrm{B}$ and $\mathrm{Cl}$ at Site 796.

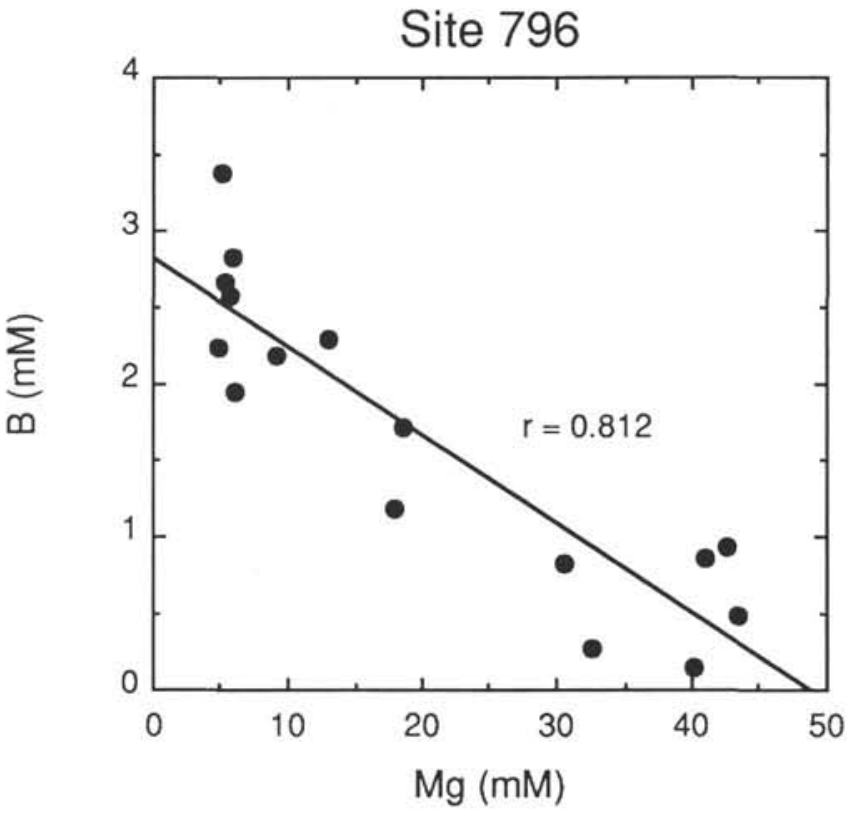

Figure 8. Correlation between $\mathrm{B}$ and $\mathrm{Mg}$ at Site 796.

suggests that the same process is responsible for the $\delta \mathrm{D}$ and $\delta^{18} \mathrm{O}$ depletion observed in many cores recovered during DSDP/ODP (Lawrence and Gieskes, 1981).

At Site 796 a negative anomaly in $\mathrm{D} / \mathrm{H}$ of about $10 \%$ in $50 \mathrm{mbsf}$ must be due to alteration reactions of volcaniclastic material. As discussed above for $\delta^{18} \mathrm{O}$, the decomposition of methane clathrates would shift the $\delta \mathrm{D}$ of the interstitial waters in the opposite direction. Unfortunately, little information is available on the isotopic exchange between methane, which is characterized by $\delta \mathrm{D}$ values of about -200 \%o (Hoefs, 1987), and pore water. Also the "heavy" counterpart in the solid phases, which is needed for mass balance considerations, has not yet been observed. Alteration products of volcanic materials are enriched in $\mathrm{H}$ and not in $\mathrm{D}$. But it should also be mentioned that a large fraction of the water present in marine sediments has never been investigated. Only fractions of the interstitial water are retrieved during squeezing, and even less water (the structural water) is analyzed in the solids. 

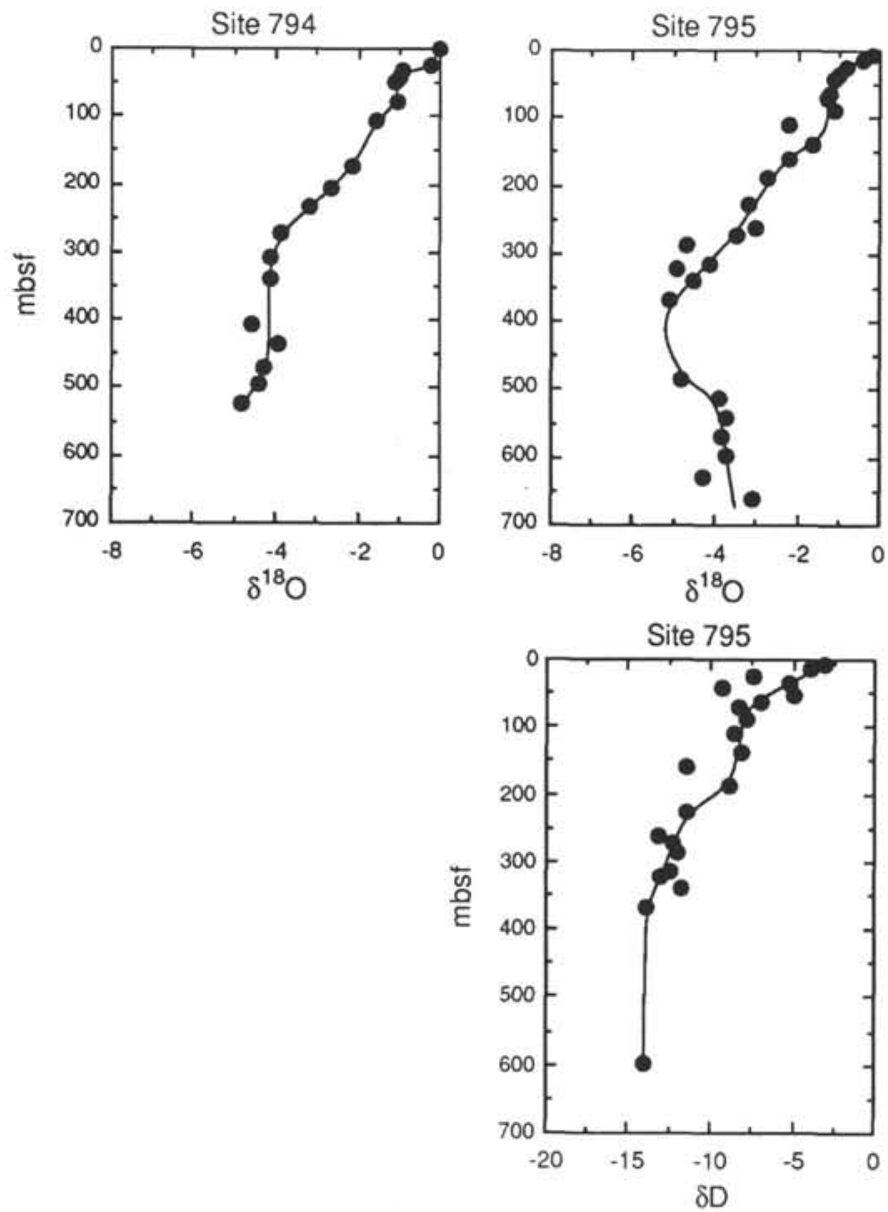

Figure 9. $\delta \mathrm{D}$ and $\delta^{18} \mathrm{O}$ in pore waters from the Japan Sea.

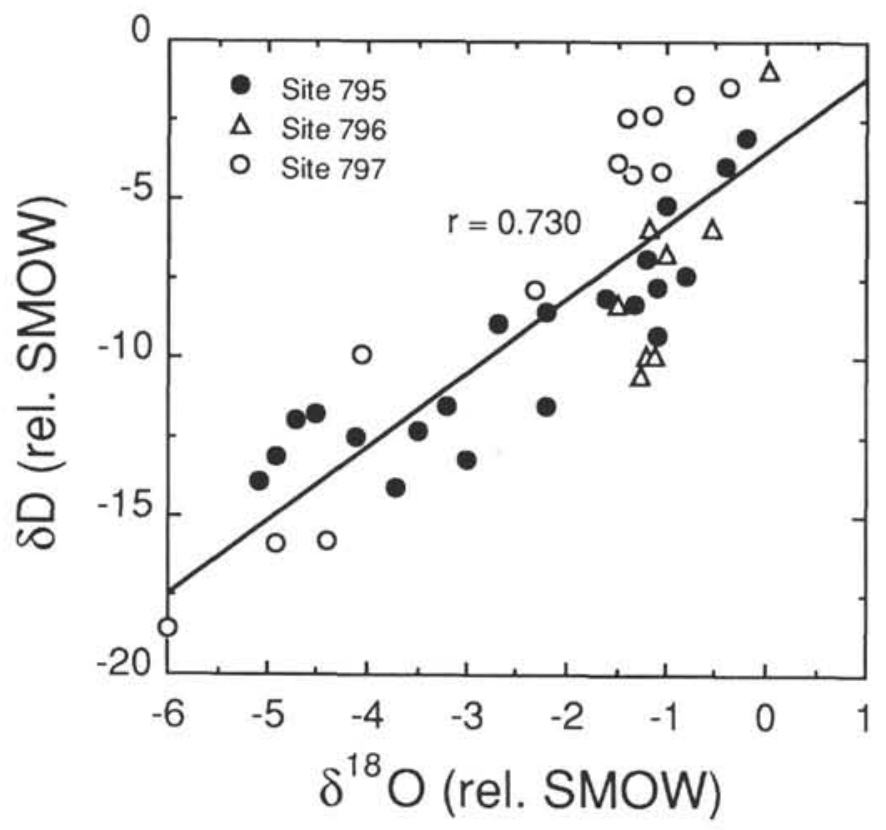

Figure 10. Correlation between $\delta \mathrm{D}$ and $\delta^{18} \mathrm{O}$ in pore waters from the Japan Sea.
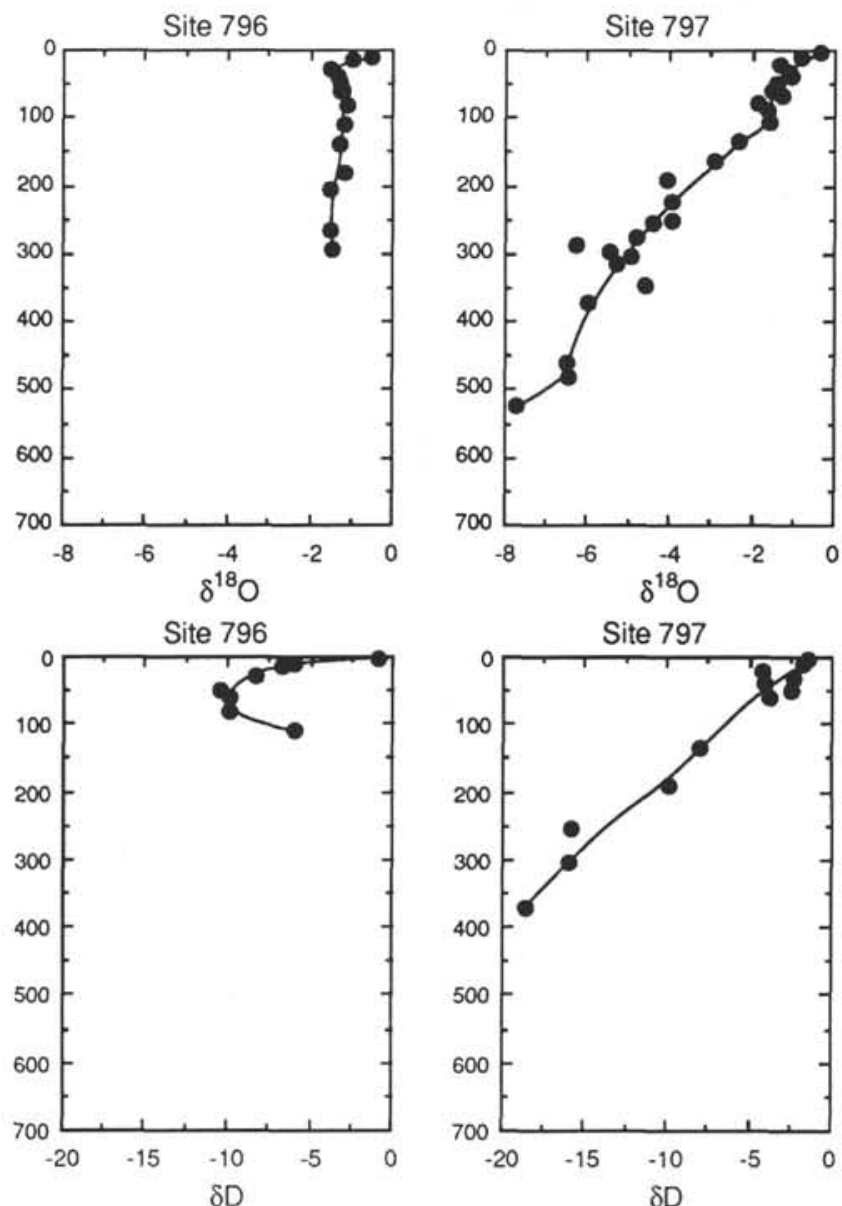

\section{Sr Isotopes}

The $\mathrm{Sr}$ isotopic composition of selected pore water samples was measured at all sites to determine whether the observed increase in $\mathrm{Sr}$ concentration with increasing burial depth results from carbonate recrystallization or alteration processes involving volcanogenic material (Fig. 11 and Table 2).

At all sites decreases in ${ }^{87} \mathrm{Sr} /{ }^{86} \mathrm{Sr}$ from values close to contemporaneous seawater (0.70925; Capo and DePaolo, 1990) to less radiogenic ratios are apparent. As for the stable isotopes discussed above, Sites 794 and 797 are characterized by very similar profiles. A relatively small decrease in the sections above the opal A/CT transition is followed by a much stronger drop in ${ }^{87} \mathrm{Sr} /{ }^{86} \mathrm{Sr}$ below this zone. This less radiogenic $\mathrm{Sr}$ isotopic composition of the interstitial waters is not related to the ${ }^{87} \mathrm{Sr} /{ }^{86} \mathrm{Sr}$ evolution of seawater during the past 13 $\mathrm{Ma}$, because, in this case, values around 0.7089 should be expected. The age of the oldest sediments recovered is about $19 \mathrm{Ma}$ (Tamaki, Pisciotto, Allan, et al., 1990), which corresponds to a seawater ${ }^{87} \mathrm{Sr} /{ }^{86} \mathrm{Sr}$ ratio of about 0.7085 . Therefore, processes of carbonate recrystallization and parallel $\mathrm{Sr}$ release seem to be of minor importance. This is supported by the generally low carbonate content of the sediments (Tamaki, Pisciotto, Allan, et al., 1990). More likely, alteration of volcanic material distributed throughout the sediments or low-temperature alteration of basement rocks is responsible for the observed trends.

As has been mentioned by Gieskes et al. $(1987,1990)$, the uptake of $\mathrm{Mg}$ and $\mathrm{K}$ by alteration of volcanic ash-rich sediments is often 

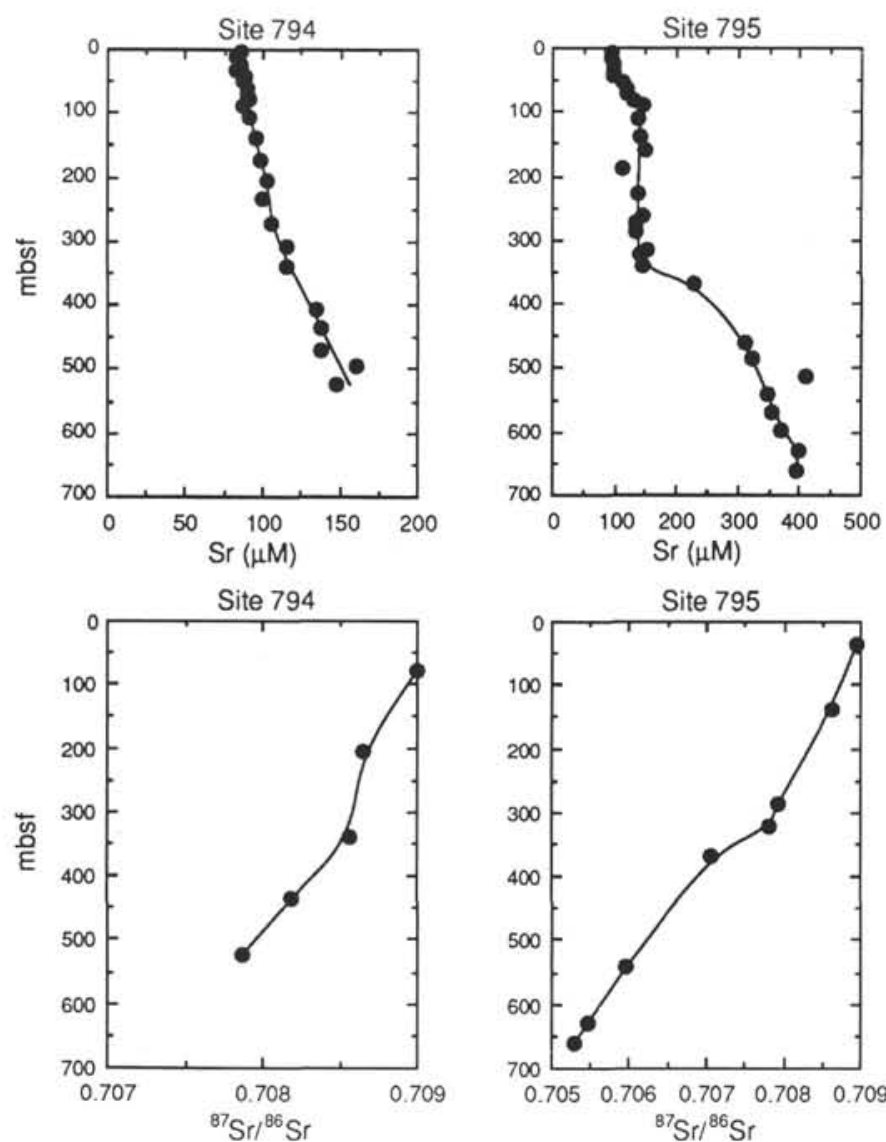

Figure $11 .{ }^{87} \mathrm{Sr} /{ }^{86} \mathrm{Sr}$ ratios of pore waters from the Japan Sea.

accompanied by strong signals in ${ }^{87} \mathrm{Sr} /{ }^{86} \mathrm{Sr}$ (Fig. 12). Sr isotopes seem to be a much more sensitive indicator than oxygen isotopes for ash alteration. In the sediment sections above the opal A/CT transformation of Sites 794 and 797, Sr isotope ratios are not lower than 0.7085 , which suggests that ash alteration in this interval is important but not very intense. It is impossible to give a more quantitative interpretation because the isotopic composition of the ash layers is unknown.

Generally, samples from below the opal A/CT transition exhibit stronger decreases in ${ }^{87} \mathrm{Sr} /{ }^{86} \mathrm{Sr}$. At Sites 794 and 797 isotope ratios decrease to 0.70787 (Site 794, $524 \mathrm{mbsf}$ ) and 0.70739 (Site 797, $525 \mathrm{mbs}$ ) in the lowermost samples analyzed. These sites are characterized by lower heat flow values (101 and $\left.103 \mathrm{~mW} / \mathrm{m}^{2}\right)$, compared to the sites from the Japan Basin (Tamaki, Pisciotto, Allan, et al., 1990).

Sites 795 and 796 are characterized by much less radiogenic isotope ratios even above the opal A/CT transition (Fig. 11). This may result from the higher proportion of volcanic ash in these units or a much stronger signal from basement alteration processes. Especially at Site 796 a very strong non-radiogenic signal is evident even in the uppermost sample analyzed $(0.7081,9 \mathrm{mbsf})$, and values around 0.70667 are seen in the upper $200 \mathrm{~m}$ of this site. Since very strong signals from intense alteration of ash and volcanic sands are also visible in the stable isotope ratios $\left(\delta \mathrm{D}, \delta^{11} \mathrm{~B}\right.$, and $\left.\delta^{18} \mathrm{O}\right)$ and the dissolved $\mathrm{Mg}$ profile at this site, these processes seem responsible for the ${ }^{87} \mathrm{Sr} /{ }^{86} \mathrm{Sr}$ signals as well. The $\mathrm{Sr}$ concentration profile indicates a complex behavior for this element with a net removal into alteration products in the upper parts of the sedimentary column. Only below $100 \mathrm{mbsf}$ does $\mathrm{Sr}$ release dominate over $\mathrm{Sr}$ incorporation. Unfortu-
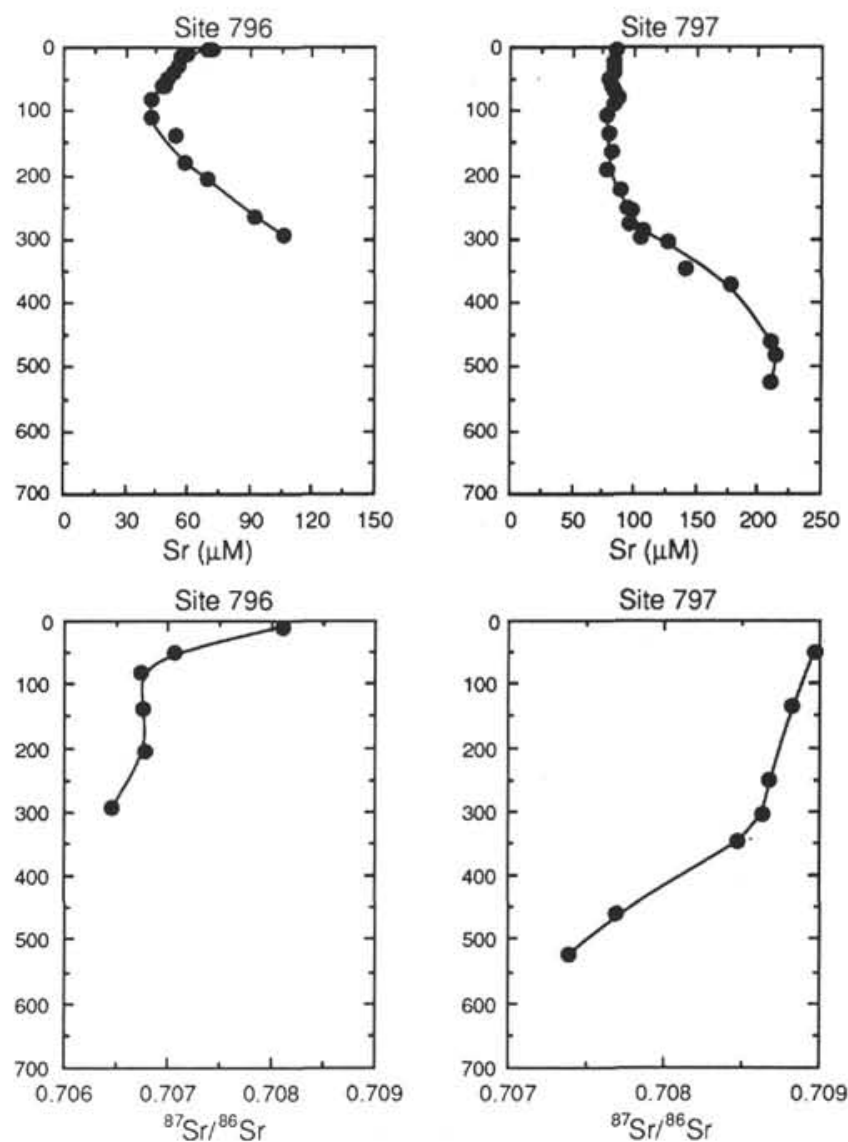

nately, samples from below 294 mbsf are not available and the influence from basement alteration therefore cannot be evaluated.

Site 795 is characterized by the lowest ${ }^{87} \mathrm{Sr} /{ }^{86} \mathrm{Sr}$ ratio observed $(0.70529$ at $662 \mathrm{mbsf})$. Fresh volcanic and volcaniclastic rocks from the "Green Tuff" region have ${ }^{87} \mathrm{Sr} /{ }^{86} \mathrm{Sr}$ ratios in the range 0.704 to 0.706 . Sr isotope ratios as low as 0.706 are reported for oil field brines from the northern Niigata Oil Field (Nakano et al., 1989). This range is comparable to the pore water data obtained during this study. Generally speaking, the sediments below the chert layers are influenced much more strongly by processes at or within the basement than by processes above this boundary.

The differences seen in the sites from the Yamato and Japan Basin may be related to either the thermal regime (Fig. 13) or the abundance of volcanic material within the sediments. Ash layers are much more abundant in the Quaternary sediments (Tamaki, Pisciotto, Allan, et al., 1990) than in the Neogene sediments. The strongest Sr-isotope signals are, by contrast, seen in the deeper parts of the sedimentary column (Fig. 11), except for Site 796. Therefore temperature may play a role in accelerating alteration reactions. At least a relationship seems to exist between $\mathrm{Ca}$ increase, ${ }^{87} \mathrm{Sr} /{ }^{86} \mathrm{Sr}$ ratio, and heat flow.

No linear relationship is apparent in the $1 / \mathrm{Sr}$ vs. ${ }^{87} \mathrm{Sr} /{ }^{86} \mathrm{Sr}$ plot for samples from Sites 794, 795, and 797 (Fig. 14). Therefore, a simple two-component mixing model, with seawater and basement rocks as end members, cannot be applied. The curvature in this plot may be due to combined effects of alteration of volcanic ash with variable ${ }^{87} \mathrm{Sr} /{ }^{86} \mathrm{Sr}$ ratios, preferential removal or incorporation of $\mathrm{Sr}$ into carbonate minerals or phosphates and alteration products, and the 


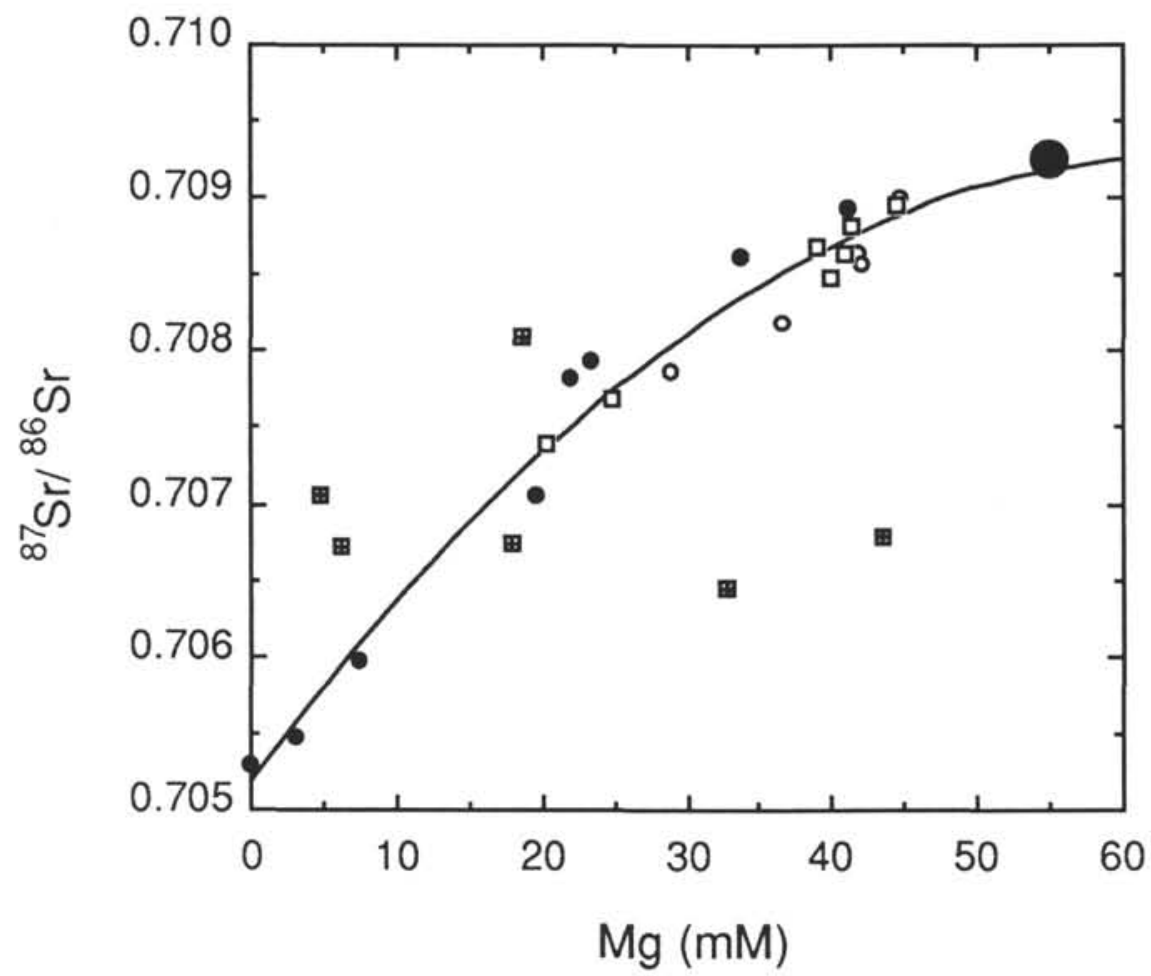
- Site 794
- Site 795
田 Site 796
$\quad$ Site 797
seawater

Figure 12. Plot of Mg vs. ${ }^{87} \mathrm{Sr} /{ }^{86} \mathrm{Sr}$ for pore waters from the Japan Sea.

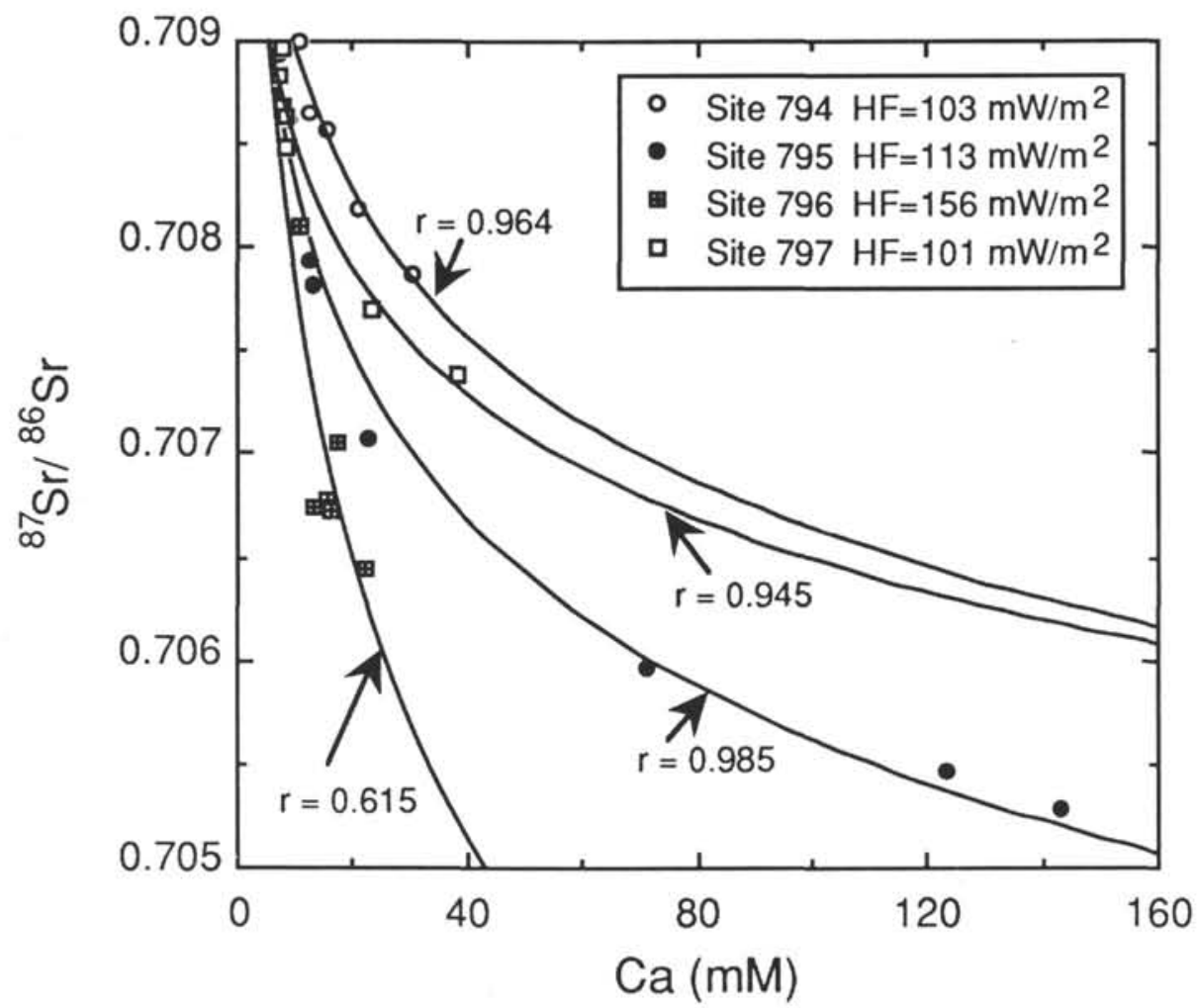

Figure 13. Plot of Ca vs. ${ }^{87} \mathrm{Sr} /{ }^{86} \mathrm{Sr}$ for pore waters from the Japan Sea and relation to heat flow data. 


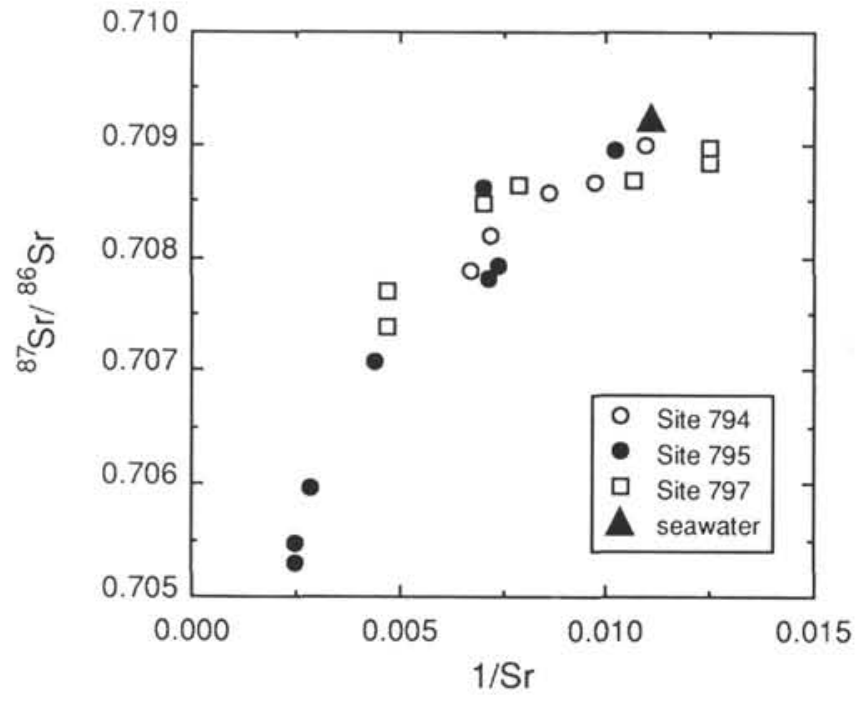

Figure 14. Plot of $1 / \mathrm{Sr}$ vs. ${ }^{87} \mathrm{Sr} /{ }^{86} \mathrm{Sr}$ ratio for pore waters from the Japan Sea.

${ }^{87} \mathrm{Sr} /{ }^{86} \mathrm{Sr}$ evolution of seawater. Only analysis of the corresponding solids will allow a more detailed interpretation of the pore water data.

\section{CONCLUSIONS}

The pore water chemistry of the Japan Sea sediments is dominated by the following processes:

1. Organic matter degradation and carbonate formation in the upper sedimentary column;

2. Alteration of ash layers and volcaniclastic sands (Site 796) in the Quaternary sections;

3. Silica diagenesis (opal A/CT transformation); and

4. Basement alteration.

Degradation of organic material influences the sulfur isotopic composition of the pore water sulfate. Sulfate reduction seems to be primarily controlled by sediment accumulation rate. The higher the sedimentation rate, the faster ${ }^{32} \mathrm{~S}$ is depleted in the interstitial water reservoir. Very heavy $\delta^{34} \mathrm{~S}$ values (up to $+93 \%$ ) have been determined for the residual sulfate reservoir, which demonstrates that barites from the "barite front" may exhibit $\delta^{34} \mathrm{~S}$ values of similar ${ }^{34} \mathrm{~S}$ enrichment.

The increase in sulfate content at greater depth seems to be related to a residual sulfate pool, which was generated during time intervals of reduced sedimentation, where diffusion could dominate over sulfate consumption or very low organic matter deposition. Processes of organic matter degradation may also have a small influence on B release in surface sediments.

The alteration of ash layers influences $\delta \mathrm{D}, \delta^{11} \mathrm{~B}, \delta^{18} \mathrm{O}$, and ${ }^{87} \mathrm{Sr} /{ }^{86} \mathrm{Sr}$ in the interstitial waters. All sites are characterized by an initial decrease in $\delta^{18} \mathrm{O}$ by 1.5 to $2.0 \%$ \% within the ash-rich Quaternary sections. This effect is most pronounced at Site 796, where volcaniclastic sands are at present being altered. At this site also a very strong $\mathrm{B}$ anomaly is seen, almost coinciding with very low $\delta^{11} \mathrm{~B}$ values, indicative of strong alteration of acidic volcanics. Here also the $\delta \mathrm{D}$ exhibits a strong negative anomaly that must be related to alteration reactions. The decrease in ${ }^{87} \mathrm{Sr} /{ }^{86} \mathrm{Sr}$ below contemporaneous seawater values at shallow depths is also very pronounced at Site 796 , in contrast to the other sites investigated. The ash layers also are the sites of B removal; B adsorption processes are accompanied by positive excursions in $\delta^{11} \mathrm{~B}$, especially at Site 795 .

The opal A/CT transformation acts as a physical and chemical boundary within the sedimentary column. It cannot yet be postulated
Table 2. Sr concentrations and ${ }^{87} \mathrm{Sr} /{ }^{86} \mathrm{Sr}$ ratios of pore waters obtained during Leg 127.

\begin{tabular}{|c|c|c|c|}
\hline & mbsf & $\mathrm{Sr}(\mathrm{mM})$ & ${ }^{87} \mathrm{Sr} f^{86} \mathrm{Sr}$ \\
\hline \multicolumn{4}{|l|}{ Site 794} \\
\hline $9 \mathrm{H}$ & 79.2 & 91 & 0.70900 \\
\hline $22 X$ & 203.4 & 103 & 0.70865 \\
\hline $36 \mathrm{X}$ & 337.9 & 116 & 0.70857 \\
\hline $15 \mathrm{R}$ & 435.2 & 138 & 0.70819 \\
\hline $24 \mathrm{R}$ & 523.6 & 148 & 0.70787 \\
\hline \multicolumn{4}{|l|}{ Site 795} \\
\hline $4 \mathrm{H}$ & 34.8 & 98 & 0.70894 \\
\hline $15 \mathrm{H}$ & 138.8 & 142 & 0.70862 \\
\hline $31 X$ & 285.1 & 135 & 0.70793 \\
\hline $35 \mathrm{X}$ & 320.6 & 140 & 0.70782 \\
\hline IR & 366.6 & 227 & 0.70707 \\
\hline $19 \mathrm{R}$ & 540.1 & 348 & 0.70597 \\
\hline $28 \mathrm{R}$ & 628.6 & 400 & 0.70547 \\
\hline $31 \mathrm{R}$ & 662.0 & 394 & 0.70529 \\
\hline \multicolumn{4}{|l|}{ Site 796} \\
\hline $2 \mathrm{H}$ & 9.2 & 60 & 0.70810 \\
\hline $6 \mathrm{H}$ & 50.2 & 50 & 0.70706 \\
\hline $11 X$ & 79.8 & 42 & 0.70673 \\
\hline $17 \mathrm{X}$ & 139.5 & 54 & 0.70675 \\
\hline $24 X$ & 205.6 & 70 & 0.70678 \\
\hline $15 \mathrm{R}$ & 294.3 & 107 & 0.70645 \\
\hline \multicolumn{4}{|l|}{ Site $\not 97$} \\
\hline $6 \mathrm{H}$ & 49.9 & 86 & 0.70897 \\
\hline $15 \mathrm{H}$ & 135.4 & 89 & 0.70883 \\
\hline $27 \mathrm{X}$ & 252.4 & 112 & 0.70868 \\
\hline $33 X$ & 304.4 & 142 & 0.70864 \\
\hline $37 X$ & 346.3 & 164 & 0.70848 \\
\hline $49 X$ & 460.0 & 211 & 0.70770 \\
\hline $5 R$ & 525.0 & 293 & 0.70739 \\
\hline
\end{tabular}

whether the silica transformation reactions have an influence on $\delta^{18} \mathrm{O}$, but certainly the broad B maximum at Site 795 seems to be related to this zone, as is the Li release. Surprisingly the B release is not reflected in the $\delta^{11} \mathrm{~B}$ profile. Chemical and isotopic gradients generally change at this boundary which separates the sedimentary column in an upper part, characterized by early diagenetic reactions, and a lower part, dominated by basement alteration processes.

The strongest influence on $\delta \mathrm{D}, \delta^{18} \mathrm{O}$, and ${ }^{87} \mathrm{Sr} /{ }^{86} \mathrm{Sr}$ is certainly due to low-temperature alteration reactions of volcaniclastics from the lowermost sedimentary units, especially the "Green Tuff," or the basement rocks themselves. In particular Site 795 is characterized by very low ${ }^{87} \mathrm{Sr} /{ }^{86} \mathrm{Sr}$ ratios in the lowermost intervals sampled; values that are close to those characteristic of the basement rocks. The $\mathrm{Sr}$ isotope profiles cannot be explained by a simple two-component mixing model with basement rocks and seawater as end members.

The observed trends in $\delta \mathrm{D}$ and $\delta^{18} \mathrm{O}$ are compatible with a "paleo ocean water reservoir" within Layer II, as proposed by Lawrence and Gieskes (1981). The basement rocks also seem to be the place where $\mathrm{B}$ is removed from interstitial waters and finally fixed in alteration products.

The study of pore waters from the Japan Sea has demonstrated the involvement of Layer I and Layer II of the oceanic crust in diagenetic processes. To further quantify these effects, the investigation of the solid phases, especially the newly forming mineral fractions, seems necessary.

\section{ACKNOWLEDGMENTS}

We thank the scientific and technical crew of Leg 127 for support during sampling and analysis. Special thanks go to R. Skrandies and 
D. Curdt for developing the plastic-lined pore-water squeezer, which performed so well during Leg 127 . We gratefully acknowledge the PREUSSAG AG for providing the Al used for the construction of the squeezer. Colleagues from the night shift, thanks for the good music, especially the Oregon Peace Choir provided by Luis Pinto. We further acknowledge the generous scientific and analytical support provided by J. Hoefs, H. Nielsen, U. Haack, J. Erzinger, and J. Gieskes. R. Przybilla kindly helped develop the oxygen isotope micro-equilibration technique. We would further like to acknowledge the helpful comments given by J. Gieskes, W. P. Leeman and an anonymous reviewer. This study was funded by the German ODP SPP (German Science Foundation).

\section{REFERENCES}

Berner, R. A., 1978. Sulfate reduction and the rate of deposition of marine sediments. Earth Planet. Sci. Lett., 37:492-498.

Bruland, K. W., 1983. Trace elements in seawater. In Riley, J. P., and Chester, R. (Eds.), Chemical Oceanography, Vol. 8. Academic Press (London), 157-220.

Brumsack, H.-J., and Gieskes, J. M., 1983. Interstitial water trace-metal chemistry of laminated sediments from the Gulf of California, Mexico. Mar. Chem., 14:89-106.

Brumsack, H.-J., 1986. The inorganic geochemistry of Cretaceous black shales (DSDP Leg 41) in comparison to modern upwelling sediments from the Gulf of California. In Summerhayes, C. P., and Shackleton, N. J. (Eds.), North Atlantic Palaeoceanography. Geol. Soc. London Spec. Publ. 21:447-462.

Capo, R. C., and DePaolo, D. J., 1990. Seawater strontium isotopic variations from 2.5 million years ago to the present. Science, 249:51-55.

Gieskes, J. M., 1981. Deep-sea drilling interstitial water studies: implications for chemical alteration of the oceanic crust, layers I and II. In Warme, J. E., et al. (Eds.), The Deep Sea Drilling Project: A Decade Of Progress. SEPM Spec. Publ. No. 32:149-167.

Gieskes, J. M. and Lawrence, J. R., 1981. Alteration of volcanic matter in deep sea sediments: evidence from the chemical composition of interstitial waters from deep sea drilling cores. Geochim. Cosmochim. Acta, 45:1687-1703.

Gieskes, J. M., and Peretsman, G., 1986. Water chemistry procedures aboard JOIDES Resolution-some comments. ODP Tech. Note, 5: College Station, TX (Ocean Drilling Program).

Gieskes, J. M., Lawrence, J. R., Perry, E. A., and Elderfield, H., 1987. Chemistry of interstitial waters and sediments in the Norwegian-Greenland Sea, Deep Sea Drilling Project Leg 38. Chem. Geol., 63:143-155.

Gieskes, J. M., Vrolijk, P., and Blanc, G., 1990a. Hydrogeochemistry of the Northern Barbados accretionary complex transect: Ocean Drilling Project Leg 110. J. Geophys. Res., 95 (B6):8809-8818.

Gieskes, J. M., Blanc, G., Vrolijk, P., Elderfield, H., and Barnes, R., 1990b. Interstitial water chemistry-major constituents. In Moore, J. C., Mascle, A., et al., 1990. Proc., ODP, Sci. Results, 110: College Station, TX (Ocean Drilling Program), 155-178.

Goldhaber, M. B., and Kaplan, I. R., 1980. Mechanisms of sulfur incorporation and isotope fractionation during early diagenesis in sediments of the Gulf of California. Mar. Chem., 9:95-143.

Harder, H., 1973. Boron. In Wedepohl, K. H. (Ed.) Handbook of Geochemistry, II-1: New York (Springer).

Hoefs, J., 1987. Stable Isotope Geochemistry, 3rd Edition: New York (Springer).

Iijima, A., Tada, R., and Watanabe, Y., 1988. Developments of Neogene sedimentary basins in the northeastern Honshu arc with emphasis on Miocene siliceous deposits. J. Fac. Sci. Univ. Tokyo, 21:417-446.

Ingle, J. C., Jr., Suyehiro, K., von Breymann, M. T., et al., 1990. Proc., ODP. Init. Repts., 128: College Station, TX (Ocean Drilling Program).

Jenden, P. D., and Gieskes, J. M., 1983. Chemical and isotopic composition of interstitial water from Deep Sea Drilling Project Sites 533 and 534. In Sheridan, R. E., Gradstein, F. M., et al., Init. Repts. DSDP, 76: Washington (U.S. Govt. Printing Office), 453-461.

Kalil, E. K., and Goldhaber, M., 1973. A sediment squeezer for removal of pore waters without air contact. J. Sed. Petrol., 43:553-557.
Kastner, M., and Gieskes, J. M., 1976. Interstitial water profiles and sites of diagenetic reactions, Leg 35, DSDP, Bellinghausen Abyssal Plain. Earth Planet. Sci. Lett., 33:11-20.

Kiba, T., and Kishi, I., 1957. Microcolorimetric determination of sulfate by reduction to hydrogen sulfide with tin(II)-strong phosphoric acid. Chem. Soc. Japan Bull., 30:44-48.

Lawrence, J. R., and Gieskes, J. M., 1981. Constraints on water transport and alteration in the oceanic crust from the isotopic composition of pore water. J. Geophys. Res., 86 (B9):7924-7934.

Manheim, F. T., 1966. A hydraulic squeezer for obtaining interstitial water from consolidated and unconsolidated sediments. U.S. Geol. Surv. Prof. Pap. 550-C: C256-C261.

Manheim, F. T., Sayles, F. L., and Waterman, L. S., 1972. Interstitial water studies on small core samples, Deep Sea Drilling Project, Leg 12. In Laughton, A. S., Berggren, W. A., et al., Init. Repts. DSDP, 12: Washington (U.S. Govt. Printing Office), 1193-1200.

Manheim, F. T., and Sayles, F. L., 1974. Composition and origin of interstitial waters of marine sediments, based on deep sea drill cores. In Goldberg, E. D. (Ed.), The Sea, Vol. 5. New York (Wiley \& Sons), 527-568.

Masuzawa, T., Kanamori, S., and Kitano, Y., 1980. The reversible effect of temperature on the chemical composition of interstitial water of marine sediment. J. Oceanogr. Soc. Jpn., 36:68-72.

McDuff, R. E., 1978. Conservative behavior of calcium and magnesium in the interstitial waters of marine sediments: identification and interpretation [Ph.D. dissert.]. University of California, San Diego.

, 1981. Major cation gradients in DSDP interstitial waters: the role of diffusive exchange between seawater and upper oceanic crust. Geochim. Cosmochim. Acta, 45:1705-1713.

Mengel, K., and Hoefs, J., 1990. $\mathrm{Li}-\delta^{18} \mathrm{O}-\mathrm{SiO}_{2}$ systematics in volcanic rocks and mafic lower crustal granulite xenoliths. Earth Planet. Sci. Lett., 101:42-53.

Nakano, T., Kajiwara, Y., and Farrell, W., 1989. Strontium isotope constraint on the genesis of crude oils, oil-field brines, and Kuroko ore deposits from the Green Tuff region of northeastern Japan. Geochim. Cosmochim. Acta, 53:2683-2688.

Palmer, M. R., and Sturchio, N. C., 1990. The boron isotope systematics of the Yellowstone National Park (Wyoming) hydrothermal system: a reconnaissance. Geochim. Cosmochim. Acta, 54:2811-2815.

Perry, E. A., Jr., Gieskes, J. M., and Lawrence, J. R., 1976. Mg, Ca and $\mathrm{O}^{18} / \mathrm{O}^{16}$ exchange in the sediment-pore water system, Hole 149, DSDP. Geochim. Cosmochim. Acta, 40:413-423.

Ronov, A. B., Grinenko, V. A., Girin, Y. P., Savina, L. I., Kazakov, G. A., and Grinenko, L. N., 1974. Effects of tectonic conditions on the concentration and isotope composition of sulfur in sediments. Geochem. Intern., 11:1246-1272.

Sakai, H., 1971. Sulfur and oxygen isotopic study of barite concretions from banks in the Japan Sea off the northeast Honshu. Geochem. J. Jpn., 5:79-93.

Sholkovitz, E., 1973. Interstitial water chemistry of the Santa Barbara Basin sediments. Geochim. Cosmochim. Acta, 37:2053-2073.

Spivack, A. J., 1986. Boron isotope geochemistry [Ph.D. dissert.]. WHOI/MIT, Boston.

Spivack, A. J., Palmer, M. R., and Edmond, J. M., 1987. The sedimentary cycle of the boron isotopes. Geochim. Cosmochim. Acta, 51:1939-1949.

Tamaki, K., 1988. Geological structure of the Japan Sea and its tectonic implications. Bull. Geol. Surv. Jpn., 39:269-365.

Tamaki, K., Pisciotto, K., Allan, J., et al., 1990. Proc. ODP, Init. Repts., 127: College Station, TX (Ocean Drilling Program).

Date of initial receipt: 1 April 1991

Date of acceptance: 25 November 1991

Ms 127/128B-165 


\section{APPENDIX}

A Plastic-lined Squeezing Device for the Recovery of Uncontaminated Interstitial Waters

Interstitial waters of marine sediments represent the second largest reservoir of water on earth, amounting to more than $0.2 \cdot 10^{18}$ tons. Since the quantity of elements in solid phases exceeds those in pore waters by a large amount (McDuff, 1978), diagenetic reactions are much more easily recognized in the chemical composition of interstitial waters than from the study of the solid phases alone (Gieskes, 1981).

Pore water studies have been an integral part of the on board work since initiation of the DSDP. During the past decades the analytical work has centered on the analysis of major ions $(\mathrm{Mg}, \mathrm{Ca}, \mathrm{Sr}, \mathrm{K}, \mathrm{Na})$, which display concentration-depth gradients in pore waters (McDuff, 1981) but behave conservatively in seawater. Since much progress has recently been made in the analysis of trace constituents in seawater (Bruland, 1983), we felt that an alternative to the well-established stainless steel squeezer (Manheim, 1966; Manheim and Sayles, 1974) should be developed in order to minimize potential contamination during pore water retrieval. Trace metal pore water data are essentially unknown for depths greater than 10 mbsf, even though later diagenetic reactions may have an influence on the abundance and distribution of trace metals in certain sediment types.

A number of different methods exist for obtaining interstitial water samples from small volumes of surficial sediments. These methods include a standard filter press that operates by gas displacement of the fluid (e.g., Hartmann, 1965), low-pressure and plastic-lined mechanical squeezers (e.g., Kalil and Goldhaber, 1973), and centrifugation techniques (e.g., Sholkovitz, 1973).

Whereas these separation techniques work well for high-porosity sediments, they are less effective for studies of deep-sea drill cores, which are much more consolidated. Gas displacement, low-pressure, or centrifugation techniques do not work because too little, if any, water will be obtained. Only high-pressure squeezing techniques seem to be effective for drill cores from greater depth.

\section{Construction of the Squeezer}

Here we want to give a brief description of the major parts of the plastic-lined squeezer. Part sizes of the apparatus are not given, because these depend on the diameter of the polycarbonate (PC)-filters that are commercially available. Here we used $0.4-\mu \mathrm{m}$ PC filters $47 \mathrm{~mm}$ in diameter.

The squeezer consists of two parts: the outer Al cylinder and piston and the inner polyamide (PA) liners and teflon (PTFE, PFA) filter holders (Fig. A1). The construction is a combination of the Manheim and Sayles (1974) steel-squeezer, which is resistant up to pressures of $1000 \mathrm{~kg} / \mathrm{cm}^{2}$, and the Kalil and Goldhaber (1973) low-pressure plastic-lined squeezer, which is made from Plexiglass and PVC.

During operation, the sediment and interstitial water, when loaded into the sample chamber, are in direct contact only with precleaned plastic material (PA, PTFE, PFA). Metal parts are always covered by PA. For the liner and support plate PA was used, because PTFE is much less resistant against higher pressures and is easily deformed. Instead of using O-rings, we developed self-sealing PTFE lips (Fig. A2). These work like a brake cylinder; the PTFE lips fit tightly with the Al-supported PAliner when pressure increases. Under normal working conditions these lips may be used several times before they wear out. The filter holder consists of a 70- $\mu \mathrm{m}$ PFA net, which is situated in a small cavity centered around the water outlet of the PTFE lip. Pore water, which is squeezed through the $0.4-\mu \mathrm{m}$ PC filter, percolates into the PFA tissue and leaves the squeezer at both sides through 1-mmi.d. PTFE tubing, which is connected to the PTFE lips. If necessary, the upper PTFE lip can be replaced by a PTFE lip without a filter and water outlet. Finally, the water is seized in precleaned PTFE or PE vials or syringes. After filtration and acidification, the samples are kept in a refrigerator until shipboard or shorebased analysis.

\section{Materials}

The outer metal support cylinder, the metal piston, and the base plate are made from seawater-proof high-tension $\mathrm{Al}\left(510 \mathrm{~N} / \mathrm{mm}^{2}\right.$, VAW Leichtmetall \# AL/ZN/MG/CU 0.5 F47). The lower part of the cylindrical Al support was constructed with a wall thickness of $15 \mathrm{~mm}$ in the high-pressure zone, in order to avoid rupture.

The base plate (Fig. A1) was machined from a 3-cm Al disk. A 5-mm-deep central groove was milled into the base plate to serve as an opening for the PTFE tubing water outlet. Two clamps were machined to the base plate as integrative parts to prevent upward movement of the cylindrical Al-support when higher pressures are applied. The upper pore water outlet tubing leaves the $\mathrm{Al}$-piston through a small hole at the upper rim of the Al-piston. The PTFE tubing is protected by a larger (5-mm-i.d.) PTFE tubing, which serves as a conduit.

The inner and outer plastic liner and the plastic support plate are made from PA. This material is much more pressure resistive than PTFE or PFA but is attacked by stronger mineral acids. Therefore, care has to be taken during cleaning procedures with diluted acids.

The inner filter holders are made from PTFE and serve as seals to prevent mud leakage (Fig. A2). These lips have a 0.5 -mm-deep cavity for the PFA net, which serves as a base for the polycarbonate (PC) filters and allows interstitial water to leave the squeezer through a single hole, connected to a PTFE tubing of $1 \mathrm{~mm}$ diameter. Several attempts were made to use a perforated PTFE disk instead of the PFA net as a filter support. But according to our experience a much higher pressure may be exerted on the much simpler PFA net construction.

Pressures up to $1000 \mathrm{~kg} / \mathrm{cm}^{2}$ were successfully employed by the instrument, and pore waters were retrieved from depths of as much as $700 \mathrm{mbsf}$ in the Japan Sea. There was essentially no difference in performance compared to the steel-squeezer. During onshore laboratory experiments we were able to acquire small amounts of water from a clay layer within Permian evaporites that contained less than $3 \%$ water.

\section{Comparison of the Steel and Plastic Squeezers}

Pore waters have been retrieved aboard ship by both squeezers in order to evaluate whether any differences in the chemical composition of the interstitial waters are occurring. As a result of the different acquisition methods for the water (syringe vs. open snap-cap vial), slight differences in $\mathrm{pH}$ and alkalinity were observed. We think that this results from equilibration of the fluids with $\mathrm{CO}_{2}$ from the atmosphere.

A comparison of the individual data sets obtained by both squeezers is shown in Figure A3. For the major and minor ions shown here a significant difference cannot be observed. Slight deviations from the 1:1 relation most likely result from analytical noise. For methods with a relatively high precision $(\mathrm{Ca}-$ and Mg-titration, $\mathrm{K}, \mathrm{Li}$, and $\mathrm{Rb}$ AAS determinations in emission mode, and $\mathrm{SO}_{4}$ by ion chromatography; Gieskes and Peretsman, 1986) the results are essentially identical (correlation coefficients better than 0.96). Larger, but nonsystematic variations are seen for the colorimetric methods $\left(\mathrm{NH}_{4}, \mathrm{Si}\right)$ with overall lower precision. It may, therefore, be concluded that there are no systematic differences in the chemistry of the two sets of pore water data. Unfortunately, this comparison could not yet be drawn with respect to trace metals.

There has also been much debate about temperature of squeezing effects (Manheim and Sayles, 1974; Spivack, 1986). These are probably only relevant in samples from surface cores. In particular, increases in $\mathrm{K}, \mathrm{Si}$, and $\mathrm{B}$ and decreases in $\mathrm{Mg}$ have been observed. As Masuzawa et al. (1980) pointed out, these effects are reversible and, therefore, squeezing at in-situ conditions may be 
useful. But we further want to note that temperature rises when approaching basement. In the Japan Sea temperatures above $60^{\circ} \mathrm{C}$ have been reached close to basement (Tamaki, Pisciotto, Allan, et al., 1990), where pore water samples could still be retrieved. Therefore, these samples should be heated accordingly upon squeezing. The plastic squeezer may be easily equipped with a thermostat-controlled cooling or heating device at the outer $\mathrm{Al}$ support cylinder.

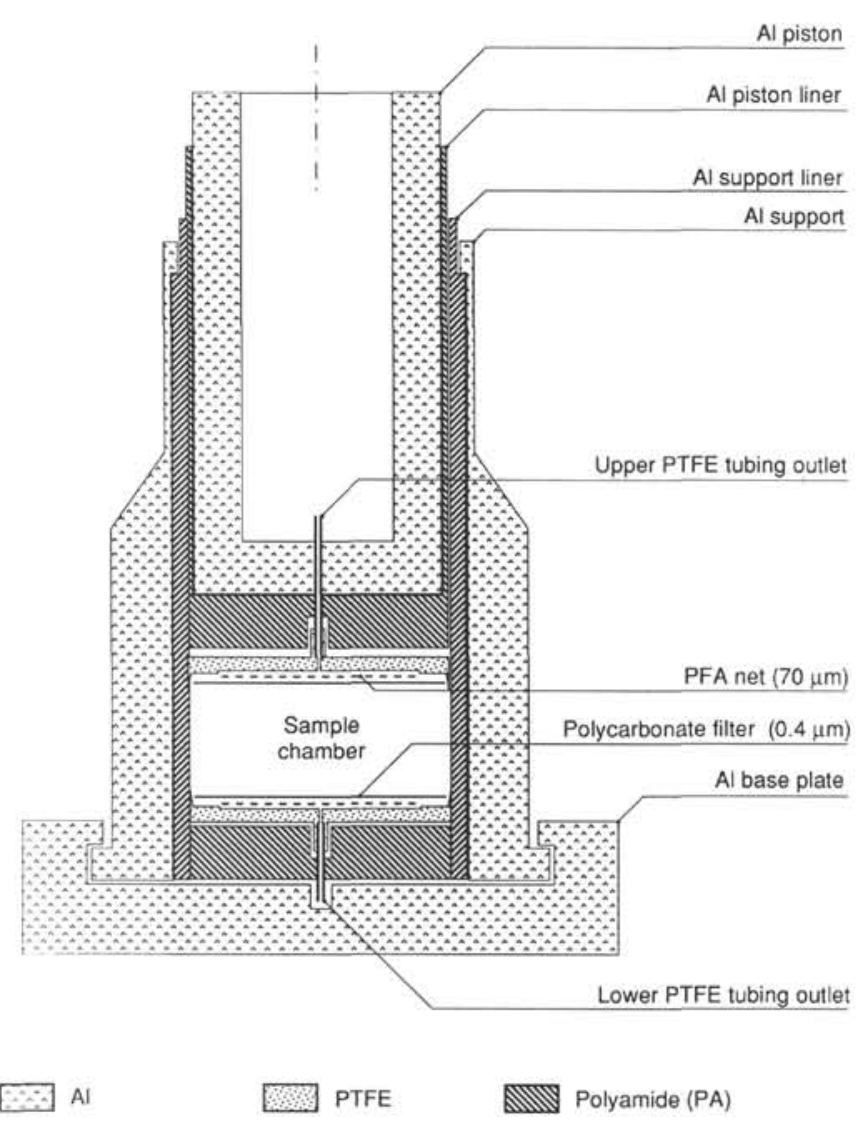

Figure Al. Plastic-lined squeezer cross section.

\section{Conclusions}

The newly developed plastic-lined squeezer employed during routine operations aboard JOIDES Resolution proved to be an alternative to the well-established Manheim stainless-steel squeezer. A comparison of the chemical composition of the interstitial waters obtained by both squeezers revealed no observable differences.

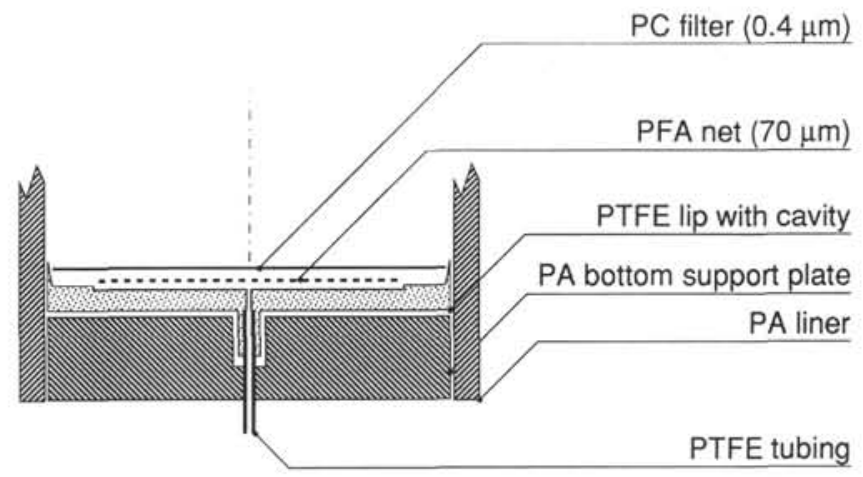

Figure A2. Cross section through the bottom plate and filter holder showing details of the PTFE lip construction. 

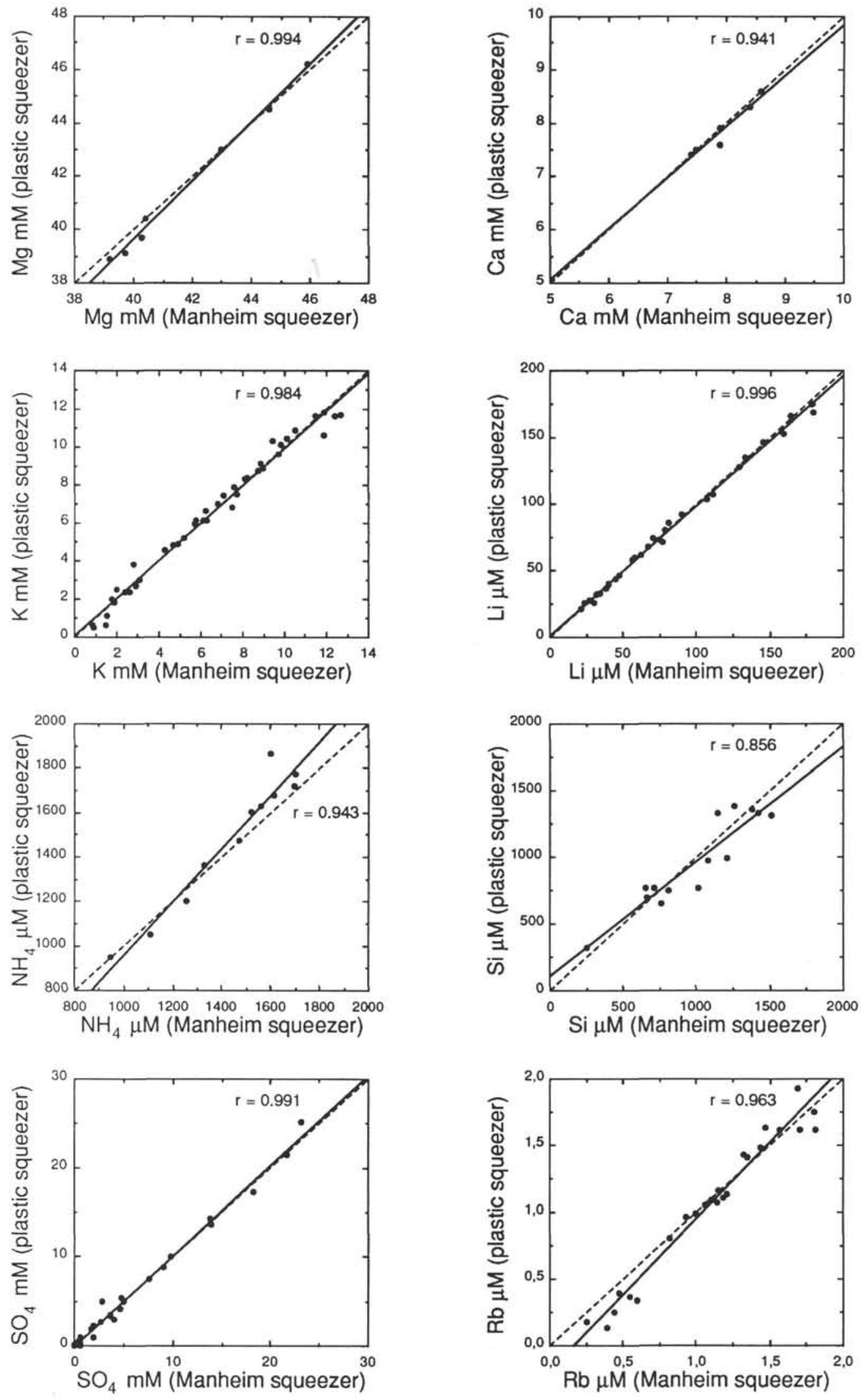

Figure A3. Comparison of the chemical data of interstitial waters obtained with the new plastic-lined squeezer and the conventional Manheim squeezer during routine shipboard analysis. 